\title{
Exposed: Venture Capital, Competitor Ties, and Entrepreneurial Innovation
}

\section{Citation}

Cox Pahnke, Emily, Rory McDonald, Dan Wang, and Benjamin Hallen. 2015. “Exposed: Venture Capital, Competitor Ties, and Entrepreneurial Innovation." Academy of Management Journal 58 (5): 1334-60. https://doi.org/10.5465/amj.2012.0777.

\section{Permanent link}

http://nrs.harvard.edu/urn-3:HUL.InstRepos:37907085

\section{Terms of Use}

This article was downloaded from Harvard University's DASH repository, and is made available under the terms and conditions applicable to Other Posted Material, as set forth at http:// nrs.harvard.edu/urn-3:HUL.InstRepos:dash.current.terms-of-use\#LAA

\section{Share Your Story}

The Harvard community has made this article openly available.

Please share how this access benefits you. Submit a story.

Accessibility 


\title{
EXPOSED: VENTURE CAPITAL, COMPETITOR TIES, AND ENTREPRENEURIAL INNOVATION
}

\author{
EMILY COX PAHNKE \\ University of Washington \\ RORY MCDONALD \\ Harvard Business School \\ DAN WANG \\ Columbia University \\ BENJAMIN HALLEN \\ University of Washington
}

\begin{abstract}
This study investigates the impact of early relationships on innovation at entrepreneurial firms. Prior research has largely focused on the benefits of network ties, documenting the many advantages that accrue to firms embedded in a rich network of interorganizational relationships. In contrast, we build on research emphasizing potential drawbacks to examine how competitive exposure, enabled by powerful intermediaries, can inhibit innovation. We develop the concept of "competitive information leakage," which occurs when firms are indirectly tied to their competitors via shared intermediary organizations. To test our theory, we examine every relationship between entrepreneurial firms and their venture capital investors in the minimally invasive surgical device segment of the medical device industry over a 22-year period. We find that indirect ties to competitors impede innovation, and that this effect is moderated by several factors related to the intermediary's opportunities and motivation to leak important information.
\end{abstract}

\section{INTRODUCTION}

In 2009, the venture capital firm Mohr Davidow announced an investment in Navigenics, a direct competitor of the personal genomics startup 23andMe in which it had invested earlier. This move led some observers to comment that "losing one of your main investors to a competitor is not a good sign" (Rao, 2009). Others speculated about the risk of unwanted

We would like to thank Riitta Katila, Kathy Eisenhardt, Tom Byers, Steve Barley, Mark Granovetter, Warren Boeker, Kevin Steensma, and Francisco Polidoro, as well as our editor, Tim Pollock, and three anonymous reviewers. We received helpful comments from audience members at the West Coast Research Symposium and from seminar participants at Stanford University, INSEAD, the University of Washington, the National University of Singapore, and the University of Texas at Austin. Karan Gandhi and Amanda Gonzalez assisted capably with this research. We acknowledge and appreciate the generous funding provided by the Ewing Marion Kauffman Foundation, the National Science Foundation, and the Stanford Technology Ventures Program. knowledge transfer, which could undercut 23andMe's competitive advantage. Another entrepreneur, commenting on a similar case in which they had been involved, expressed unease about losing an innovative edge by becoming "part of a hedging game where [intellectual property] may be leaked in one direction or the other" (Lacy, 2010). More generally, a scenario such as this sheds light on an important source of tension for entrepreneurial firms, albeit one that has received short shrift theoretically: What are the downsides of early relationships for new firms that are trying to innovate?

A growing body of research has suggested that entrepreneurial firms' early relationships promote their success by helping them overcome initial resource constraints (Katila, Rosenberger, \& Eisenhardt, 2008; Pahnke, Katila \& Eisenhardt, in press), rise above disadvantaged social positions (Hallen, 2008; Vissa, 2011), and gain access to such diverse audiences as potential investors (Gulati \& Higgins, 2003), alliance partners (Pollock \& Gulati, 2007), the media (Santos \& Eisenhardt, 2009), and customers (Elfring \& Hulsink, 
2003). Conceptually, researchers have framed relationship formation as an effective strategy that entrepreneurial firms can employ to help overcome their "liability of newness" (Baum, Calabrese, \& Silverman, 2000; Stinchcombe, 1965) and to grow and develop (Khaire, 2010; Stuart, 2000). Accordingly, new firms are unlikely to survive, let alone thrive, without these critical relationships.

This largely optimistic perspective on interfirm relationships prevails in research on innovation that has posited that positive outcomes are contingent on the partnerships that young firms form. Powell, Koput, and Smith-Doerr (1996), for example, famously argued that the "locus of innovation" resides not in isolated firms but in interfirm networks, or relationships among organizations with complementary knowledge repositories. Entrepreneurship researchers have also shown that innovation arises from critical resources provided by partners, including tangible financial resources (Pahnke, Katila, \& Eisenhardt, in press) and such intangible resources as social status, technical knowledge, and expert advice (Baum et al., 2000; Stuart, Hoang, \& Hybels, 1999; Zhang \& Li, 2010). In sum, the advice "don't go it alone" (Baum et al., 2000) accurately summarizes existing research on new firms.

But, the Mohr Davidow anecdote hints at a potential drawback for new ventures. By forming ties with a partner, an entrepreneurial firm may risk exposing its technological core to competitors that share the same partners (Dushnitsky \& Shaver, 2009). This risk becomes particularly acute when a powerful intermediary (such as Mohr Davidow) has both opportunity and motivation to redirect information flows indirectly between partners (Burt, 1999; Rogan, 2013) and when innovation outcomes are predicated on competitors' actions (Katila \& Chen, 2008; Mansfield, 1985). Intermediaries have their own objectives (Edelman, 2014), and may pursue interests that do not align with those of the enterprises with which they partner (Khurana, 2002; Pollock, 2004). Moreover, innovation outcomes are competitively interdependent, such that success and failure depend critically on the nature and timing of exposure to competitors (Boudreau, Lakhani, \& Lacetera, 2011; Turner, Mitchell, \& Bettis, 2010).

This study investigates how early investment relationships that expose entrepreneurial firms to their competitors via a shared intermediary impact innovation. Lacking power, status, and resources, entrepreneurial firms wield little sway over the relationships that their partners form with other firms and may have little control over what information gets shared (Katila et al., 2008). For them, competition affects innovation outcomes since getting an idea to market as a commercial product determines which firms thrive and which falter (Schoonhoven, Eisenhardt, \& Lyman, 1990). Building on these ideas, we develop a theory of competitive information leakage via indirect ties, and conceptualize how and why powerful intermediaries redirect important information that negatively impacts some entrepreneurial firms' innovation. Using a unique dataset consisting of 22 years of product introductions and patents in the U.S. minimally invasive medical device sector, we test and find broad support for our theory. Specifically, firms that have many indirect ties to competitors are significantly less innovative than those with no such ties. This negative impact is moderated by several factors related to relationships with a shared intermediary, including the sequence of tie formation, relative commitment, and proximity to the intermediary, as well as the intermediary's status and reputation.

Our study extends network perspectives on innovation and generates novel insights for further research on strategic entrepreneurship. Our first contribution extends understanding of how network relationships can negatively impact young firms. Prior research on the negative consequences of relationships has focused on direct ties between young firms (Diestre \& Rajagopalan, 2012; Katila et al., 2008; Vissa \& Chacar, 2009); we explore how indirect ties via intermediaries can have negative outcomes. We emphasize the role of these ties in enabling information outflows, or leakage (Hernandez, Sanders, \& Tuschke, 2014), whereas prior work has focused on barriers to knowledge inflows (Piezunka \& Dahlander, 2015; Stam \& Elfring, 2008; Uzzi, 1997). Second, in questioning the effectiveness of relationships as a strategy to overcome the liability of newness, we outline when indirect ties to competitors can be expected to be more or less detrimental to innovation (Ahuja, 2000). In contrast to prior network studies of how the focal firm, network composition, and environment shape network effects (Gulati, Lavie, \& Madhavan, 2011; Phelps, 2010; Shipilov, 2006), we explicate important characteristics of the intermediary brokering the relationship. Taken together, our theory and results highlight important drawbacks of connectedness, and demonstrate that certain ties have the potential to make new firms even more vulnerable-an issue that we refer to as "competitive leakage." 


\section{THEORY AND HYPOTHESES}

\section{Competitive Leakage: The Role of Indirect Ties via Intermediaries}

In a departure from earlier research on the benefits of relationships for young firms, researchers have recently turned to the negative consequences of network ties (Diestre \& Rajagopalan, 2012; Dushnitsky \& Shaver, 2009; Katila et al., 2008). However, their work has focused on direct ties and overlooked the important role of powerful intermediaries. ${ }^{1}$ In this section, we describe the antecedents that enable indirect competitive ties to form, explain why they can lead to leakage, and explore the conditions under which negative consequences may become amplified. We consider factors that influence a shared intermediary to redirect information between competitors thereby altering innovation-the process that transforms a novel idea into a useful, commercial product (Katila \& Shane, 2005).

How do indirect ties to competitors form in the first place? Prior research suggests that young firms typically begin with scant resource endowments and face an extreme form of resource dependence (Hallen \& Eisenhardt, 2012; Ozcan \& Eisenhardt, 2009). Consequently, they have little choice but to turn to partners to obtain such much-needed resources as capital, market access, and advice (Elfring \& Hulsink, 2003; Gulati \& Higgins, 2003). Because they need resources offered by partners, and because potential partners are likely to be uncertain of their quality, young firms are often obliged to disclose information about their technology and strategic direction (Dushnitsky \& Shaver, 2009). In short, early ties may necessitate substantial transparency to partners. At the same time, young firms' low-power position gives them little say in their partners' subsequent tie formation (Garg, 2013). Thus, a young firm's existing partners, in pursuit of their own agendas, may seek to engage the firm's competitors, and there may be little the firm can do to

\footnotetext{
${ }^{1}$ A small body of research has considered the impact of indirect ties-although not on innovation and not in young firms. For example, Rogan and Sorenson (2014) found that indirect ties (common clients) between global advertisers prompted low-performing acquisitions, while Hernandez et al. (2014) explored indirect board interlock ties that created the potential for knowledge leakage to rivals. Ahuja (2000) did examine innovation, but, like these other studies, focused on large established firms (not new ventures) and did not theorize the role of intermediaries.
}

discourage the formation of these indirect ties to competitors.

What makes these indirect ties insidious is that they create a pathway for information outflow, or "leakage," which can hinder young firms' innovation efforts. Unlike direct ties, into which firms enter purposefully, indirect ties form at the shared intermediary's discretion. Moreover, given the disclosure required of young firms to attract (direct) partners, there may be little they can do to stem unwelcome information flow once (indirect) ties to competitors are formed. An analog is gossip: in the same way that gossipers cede control over how the rumors they initiate are retransmitted, firms that disclose sensitive information to an intermediary cede control over how it is re-shared with the intermediary's network of affiliations (Burt, 2001). ${ }^{2}$ Von Hippel (1987: 295), observing information outflows to competitors via third parties in the steel industry, found that executives prevented direct information transfer to rivals but could not control what he called "indirect transfer." A firm's indirect ties thus pose a risk of transmitting important information about its technical approach and strategic intentions to parties with the capabilities to quickly absorb and act on that information, thus profiting at the focal firm's expense (Dushnitsky \& Shaver, 2009; Teece, 2007).

Moreover, by directing information toward one firm, an intermediary indicates that the firm is favored. By implication, less-favored firms are likely to suffer from information outflows without receiving any compensatory information inflows. Thus, indirect ties to competitors create an opportunity structure for information leakage-a structure over which young firms have little control and which puts their competitors at an information advantage. Here, innovation can be conceptualized as a competitively interdependent race. Just as a cyclist's strenuous efforts can wear the cyclist out (perhaps making him less likely to finish) and enable competitors to draft off his hard work, the significant time, resources, and cognitive effort required to turn an idea into a commercialized product can slow

\footnotetext{
${ }^{2}$ Abrahamson (2006), in his review of Global Ideas: How Ideas, Objects, and Practices Travel in the Global Economy, compared information transmission via networks to the children's game of telephone: knowledge is "translated" such that later instantiations bear little resemblance to the original. In our setting, translation is mitigated by the short path the information travels (from a firm to its competitor via a single intermediary).
} 
down or even thwart a focal firm while spurring on competitors that benefit from information leaked to them via intermediaries-thus effectively reducing the originating firm's level of innovation relative to that of its competitors. ${ }^{3}$

Core to this potential for information leakage is that intermediaries' interests diverge from those of the firms they connect (Khurana, 2002; Pollock et al., 2004), and they may use their privileged position as a hub between competitors to channel information in directions that serve their own interests. To better understand this problem, we propose theoretical arguments for a main effect and related contingencies that jointly form an overarching framework based on intermediaries' motivations to leak information. First, we argue that young firms with numerous indirect competitive ties via intermediaries are most vulnerable to information leakage, developing our arguments in the context of indirect ties brokered by venture capital firms (VCs) that invest in competing entrepreneurial firms. Then, we explore moderating factors characterizing the nature of the ties between competitors and their shared intermediaries-their sequence, relative commitment, and geographic proximity-and intermediary characteristics (status and reputation) that impact the likelihood and direction of leakage.

\section{Indirect Ties to Competitors}

Building on the idea that indirect ties to competitors may facilitate information leakage, we argue that having more such ties to competitors may undermine the innovation-based advantages that entrepreneurial firms might otherwise enjoy. As noted above, indirect ties create pathways for information outflow, enabling motivated intermediaries to redirect information in a way that prioritizes some firms at the expense of others. In our context, for example, to obtain capital and receive informed

\footnotetext{
${ }^{3}$ The value of information in an interdependent innovation task was readily apparent during the Netflix Prize competition in 2009. Teams were vying to create an algorithm with $10 \%$ improvement over Netflix's own movie-recommendation algorithm. While a Bell Labs team ultimately won, their efforts were aided by a competitor's (Simon Funk) unique insight that they (and other competitors) built on to improve their algorithms. Funk willingly disclosed the idea, abdicating any advantages he could have gleaned from his problem solving. Leakage via intermediaries can create a similar dynamic that benefits more-favored firms at the expense of less-favored firms.
}

advice from VC investors, entrepreneurs declare their proprietary advantages, maintain open communication channels, and freely share information about novel technologies and strategies without relying on non-disclosure agreements (NDAs) (Diestre \& Rajagopalan, 2012; Katila et al., 2008; Ueda, 2004). ${ }^{4}$ The intimate relationships that develop between VCs and entrepreneurs entail the kind of easy communication and frequent contact that together facilitate the transmission of tacit knowledge (Szulanski, 1996) and place entrepreneurial firms at risk for information leakage. Accordingly, to the extent that VCs choose to invest in competitors, they are likely to be well positioned to selectively direct information from one entrepreneurial firm to another-if they are motivated to do so.

Prior research suggests that VCs may indeed have incentives that would encourage investing in competitors and selectively leaking information among them. In venture capital, investors are driven primarily by their own profit objectives, interests that diverge from those of the entrepreneurs they broker between (Pollock, 2004; Pollock, Porac, \& Wade, 2004); they may even manage their connections' dependence "for their own advantage" (Pollock et al., 2004: 66). For instance, VCs often back competing firms as part of a strategy to maximize a portfolio of investments the returns from which will be driven by relatively few large winners, known as "home runs" (Dimov \& De Clercq, 2006; Gaba \& Terlaak, 2013; Kerr, Nanda, \& Rhodes-Kropf, 2014; Sahlman, 1990). Furthermore, VCs often invest in "winner-takes-all" markets in which one or a few firms capture the bulk of returns. As expectations shift about the most likely candidates to produce home runs, VCs may be inclined to redirect information from one startup to another to increase their chances of being an investor in one of the outsized winners (Gifford, 1997; Sapienza, 1992).

\footnotetext{
${ }^{4}$ This phenomenon has been described as "the paradox of disclosure": venture capital investors "are disinclined to sign NDAs ... Entrepreneurs who push NDAs on VCs look amateurish” (Dushnitsky \& Shaver, 2009: 1048).

${ }^{5}$ Interestingly, all of the venture capitalists we interviewed acknowledged that some VCs back competitors but categorically denied that their firms engaged in this practice. Moreover, in tailoring their investment approach to startups, some venture capitalists have explicitly acknowledged the skewed distribution of VC returns. For example, Andreessen Horowitz's investment thesis is predicated on the idea that "in any given year, $97 \%$ of venture capital returns [across the industry] comes from just 15 startups” (Perlroth, 2012).
} 
Although access to privileged information can sometimes generate positive spillovers for firms linked via intermediaries (Khurana, 2002), we argue that profitdriven VCs will, on average, create more negative spillovers by redirecting information to a select few focal firms at the expense of more numerous competitors. Of course, whether information spillover is positive or negative is in the eye of the beholder: firms that benefit from having information directed toward them are likely to view spillovers as positive, while information that is directed away is viewed as negative.

Accordingly, the more indirect ties to competitors a firm has through a shared VC, the lower the probability that it is the favored firm. As a result, during the innovation process of transforming an idea to a commercialized product, such a firm is more likely to have its ideas and unique insights shared with competitors and less likely to benefit from others' good ideas (because those ideas are not being directed to them). The firm will therefore introduce fewer new products. Overall, having many indirect ties to competitors renders young firms vulnerable to leakage via intermediaries, negating proprietary technological advantages, limiting positive knowledge spillovers, and undermining innovation relative to competitors.

Hypothesis 1. Entrepreneurial firms with more indirect ties to competitors via shared investors will be less innovative than firms with fewer such ties.

\section{Ties to Shared Intermediaries: Initial Investment, Commitment, and Proximity}

Initial investment. The potential for leakage, and its direction, is likely to vary with the nature of ties between young firms and intermediaries. Leakage can theoretically occur in various directions-that is, to any of the indirectly connected competitors. We argue, however, that information is most likely to flow from the earliest-formed tie to a shared intermediary (source) to firms with later-formed ties (receivers), for several reasons. First, VCs have more opportunities to learn from and aggregate information from early investments. This is because firms with the earlier-formed ties interact longer and in a more sustained way with a VC (Sahlman, 1990). Given open disclosure and the frequent intensive monitoring received (Garg, 2013), early ties are likely to provide VCs with prolonged access to core strategic insights about new technologies, promising products, or regulatory issues, which can be synthesized and directed to later investments. Second, after learning from their early investments, VCs are likely to have a better understanding of a sector's trajectory, which enhances their perceived ability to identify promising new investment opportunities within the sector. When VCs subsequently invest in a competitor, they are likely to regard the later investment as promising and will steer privileged information to it.

Third, these other mechanisms are magnified since firms that receive investments before their VCs make any competing investments are especially likely to disclose important information to these VCs. As noted by Graebner (2009), entrepreneurs experience trust asymmetries and tend to assume that other parties behave in an open and forthcoming manner. Consequently, firms that have yet to have their VCs invest in a competitor may be particularly naïve about the possibility of such investments occurring and of the potential for leakage. Prior to their VCs making any competing investments, these firms may be particularly open with VCs. In contrast, as soon as a firm shares any of its VCs with a competitor (regardless of the order of investments), concerns about competitive exposure become salient. As firms become aware of the potential for leakage, they may be more guarded and limited in what they disclose to investors to prevent future information outflows. This makes firms whose initial VCs had previously invested in competitors less susceptible to damaging leakage. Collectively, these arguments imply that information will be disproportionately siphoned away from the firm with the earliest-formed connection to a shared intermediary and retransmitted to competitors with later-formed connections. Thus, the earliest-tied firm is particularly vulnerable to leakage and to the undermining of their innovation-based competitive advantage. We hypothesize:

Hypothesis 2. The negative effect of indirect competitor ties on innovation is greater for entrepreneurial firms that were first among their competitors to form ties with shared investors.

Commitment. The commitment exhibited by an intermediary also impacts the direction of information leakage. We conceptualize "tie commitment" in terms of the frequency and intensity of resources bestowed (Guler, 2007); tie commitment signifies the extent to which a given partner is favored, preferred, or valued by the shared intermediary (Lawler \& Yoon, 1996). Among firms with indirect ties to competitors, those that have received more resources from a shared 
intermediary are apt to be less vulnerable to leakage than those that have received fewer resources. Specifically, an intermediary can direct information to favored firms to the detriment of others (Pollock et al., 2004). Consistent with this logic, Ozmel and Guler (2014) theorized that the value provided by VCs to a given portfolio company depends on factors related to the company's implicit rank in a VC's overall portfolio. Entrepreneurs who enjoy a higher standing garner special benefits from their VCs, enabling them to outperform their peers.

Just as an academic advisor may funnel information about job opportunities and fellowships gleaned from other students to her favored advisees, VC firms that are strongly committed to certain portfolio firms are apt to provide them additional assistance. In contrast, a VC is likely to channel information away from a young firm with which it has less committed ties, and that firm's innovation may be inhibited. Even while bestowing fewer resources on such firms, an intermediary is likely to continue to maintain a relationship with them, preserving its "window" on new technologies and market developments (Benson \& Ziedonis, 2009). We contend that channeling information toward the firms that have the most committed ties has the potential to amplify the skewed distribution of the VC's portfolio and enhance its expected financial returns. Thus, we argue:

Hypothesis 3. The negative effect of indirect competitor ties on innovation is greater for entrepreneurial firms with less committed ties than their competitors to shared investors.

Proximity. Our third argument on the nature of ties builds on the idea that an intermediary's geographic location affects innovation by shaping the direction of information flow (Jaffe, Trajtenberg, \& Henderson, 1993; Whittington, Owen-Smith, \& Powell, 2009). Among firms with indirect ties to competitors, we posit that there are several reasons that those more geographically distant from a shared intermediary will be more vulnerable to leakage than those that are more proximate. First, venture capital tends to be a local business, and VCs primarily invest in nearby entrepreneurial firms (Chena, Gompers, Kovner, \& Lerner, 2010; Cumming \& Dai, 2010). Proximity enables venture capital investors to perform more comprehensive and efficient due diligence on potential investments, and facilitates later monitoring of those investments (Lerner, 1995; Shane \& Cable, 2002). To the extent that VCs anticipate primarily local investing in the future, this pattern creates incentives to remain well regarded within their region-especially among entrepreneurs with whom they have previously worked and who may recommend other promising entrepreneurs. VCs are thus likely to be highly motivated to help local firms, but have weaker incentives to help distant firms, especially at the expense of more proximate ones.

Second, even if VCs do not explicitly favor one firm over another, their relative influence may also make leakage from distant to proximate investments more likely. VCs are able to exert more influence on proximate firms than on distant firms because oversight of proximate firms is less costly (Lerner, 1995) and because more informal opportunities arise for advising and influencing strategy when relationships are co-located (Whittington et al., 2009). Accordingly, even if VCs are equally partial to their distant and proximate investments, nearby firms may be more likely to absorb and implement any leaked information. A related argument is that proximity begets greater social affinity-a phenomenon referred to as the "propinquity effect" (Festinger, Schachter, \& Back, 1950; Reagans, 2011). As VCs become more familiar with their proximate investments, they gain an in-depth understanding of the firm's technology and strategic approach (giving them more opportunities to leak), but, at the same time, develop an affinity toward these firms (giving them less motivation to leak). Such tacit favoritism may limit leakage of information gained from proximate portfolio firms. Overall, due to VCs' incentives, easier information absorption by proximate entrepreneurial firms, and greater social affinity toward them, we argue:

Hypothesis 4. The negative effect of indirect competitor ties on innovation is greater for entrepreneurial firms more geographically distant than their competitors to shared investors.

\section{Intermediary Characteristics: The Role of Status and Reputation}

Leakage is also likely to vary with certain characteristics of the shared intermediary. Status and reputation are distinct but related characteristics that affect intermediaries' opportunities and motivation to leak information. Both are intangible assets of an organization that reduce others' uncertainty about engaging in economic transactions with that organization (Barron \& Rolfe, 2012; Podolny, 2005), but they differ in their origins and underlying theoretical mechanisms. "Status" refers 
to social deference, embodied in and influenced by a firm's pattern of affiliations; a firm's status is only loosely coupled with its past behaviors (Chandler, Haunschild, Rhee, \& Beckman, 2013; Rindova, Pollock, \& Hawyard, 2006). In contrast, "reputation" arises directly from examining a firm's past actions (as distinct from its affiliations) to infer its skills and knowledge (Ertug \& Castellucci, 2013). Reinforcing the distinctiveness of the two constructs, prior research has found that status and reputation are decisive in different outcomes (Chandler et al., 2013; Washington \& Zajac, 2005); this finding suggests that an intermediary's status and reputation may have distinct effects on leakage and on indirect ties.

Status. We posit that high-status intermediaries will be more likely than lower-status counterparts to leak information. First, status may influence an intermediary's beliefs about the acceptability of leaking. To the extent that affiliating with a highstatus partner is desired by others, status lends power to an intermediary in the form of control over valued resources (Macgee \& Galinsky, 2008; Pfeffer \& Salancik, 1978). In venture capital, for example, high-status investors can confer legitimacy on the otherwise status-poor ventures in which they invest (Hallen, 2008; Podolny, 2001). Moreover, those in possession of power tend to view others in an instrumental and objectified manner (Gruenfeld, Inesi, Magee, \& Galinsky, 2008); thus, VCs may see information gleaned from prior investments as a means to enhance their own success with other investments. High-status VCs may believe they are unlikely to suffer negative consequences from leaking information, and may perceive such slim risks as acceptable.

Status also mitigates the actual risks of leaking information. Specifically, since status is loosely coupled with underlying quality due to the inertia that accompanies its conferral (Podolny, 1993, 2005), high-status intermediaries are likely to feel buffered against possible threats of status loss (Phillips \& Zuckerman, 2001). High-status organizations are also afforded greater deference, insulating such intermediaries from potential leakage claims by lowstatus firms. Given such dynamics, entrepreneurial firms that suspect leakage are disinclined to air their suspicions publicly and high-status VCs can be confident that they can get away with it. Taken as a whole, this reasoning suggests that high-status VCs will be motivated and able to leak valuable information between indirectly connected competitors.
Hypothesis 5. The negative effect of indirect competitor ties on innovation is greater for entrepreneurial firms that share high-status VC investors with their competitors.

Reputation. While status is shaped by social construction, reputation is grounded in a firm's past actions and behaviors (Fombrun \& Shanley, 1990). Because of inertia in resources, capabilities, and internal processes, firms tend to behave consistently over time, so their past actions are considered a credible signal of future behavior (Weigelt \& Camerer, 1988). Drivers of a VC's reputation include the firm's recent investments, the success of those investments, and the firm's track record of attracting investment funds from institutional investors (Lee, Pollock, \& Jin, 2011). Since reputation, unlike status, needs to be continually reinforced over time, high-reputation VCs that engage in information leakage may benefit in the short term but have difficulty maintaining their reputation, as allegations of leakage could deter other entrepreneurs and hamper the VC's long-term deal flow (Hallen, Katila, \& Rosenberger, 2014; Mishina, Block, \& Mannor, 2012; Raub \& Weesie, 1990) For this reason, high-reputation VCs may have greater incentives to avoid information leakage. Unlike status, reputation does not evoke deference from others; having a high reputation may make VCs less likely to engage in egregious behaviors associated with high power. Collectively, these logics suggest that high-reputation VCs are more motivated to avoid leakage than their lower-reputation counterparts. Therefore:

Hypothesis 6. The negative effect of indirect competitor ties on innovation is attenuated for entrepreneurial firms as the reputation of their shared VC investors increases.

\section{METHODS}

\section{Research Context}

The ideal empirical setting in which to test our hypotheses was one where relationships with intermediaries were prevalent, competition was salient and identifiable, and innovation was an important and observable outcome. Given these criteria, we selected the minimally invasive surgical (MIS) device sector, a segment of the medical device industry. To augment our archival research and to triangulate our quantitative evidence (Edmondson \& McManus, 2007; Jick, 1979), we conducted semi-structured interviews with 30 informants between 2006 and 
2012. We interviewed a variety of people involved in the industry, including entrepreneurs, regulators, venture capitalists, industry experts, surgeons, and medical professors. The interviews pinpointed several features of the sector that make it an appropriate setting for our study.

First, innovation is a defining feature of the MIS device sector; it largely determines which device makers thrive and which fail. Furthermore, innovation tends to occur at "small, early-stage companies that rely heavily on venture capital" (Ackerly, Valverde, Diener, Dossary, \& Schulman, 2009). MIS firms develop new surgical devices that utilize small incisions to reduce trauma for patients and speed healing time (Mack, 2001; Pisano, Bohmer, \& Edmondson, 2001). MIS devices resemble pharmaceutical drugs in their technological complexity and stringent U.S. Food and Drug Administration (FDA) regulatory requirements-though, crucially, there are no generic medical devices. Thus, MIS firms focus intently on creating innovative new products; they have strong incentives to clear the FDA's regulatory hurdles and introduce new devices ahead of competitors. Our informants emphasized the importance of innovation (i.e., getting FDA approval), acknowledging that, as one industry analyst put it, "from an economic standpoint, there are great businesses that have been built without [other factors] but never without approval."

Second, the MIS device sector is characterized by intense competition: firms jockey for innovative positions in different MIS subsegments. Many of those whom we interviewed suggested that the market exhibits competitive interdependence, and mentioned the nature of competition as a decisive factor that governs behavior and helps determine innovation success or failure. One anxious investor, speaking of a nascent subsector, told us: "There aren't a lot of dominant positions because no one has won yet. . . . The rate of innovation has kept it possible to neutralize the other person's game with your countermove."

Another attractive feature for our purposes is that the sector is divided into distinct competitive subsegments, for each of which the FDA organizes regulatory review panels. To identify "competitors"-or "firms operating in the same industry, offering similar products, and targeting similar customers" (Chen, 1996; Chen, Katila, McDonald, \& Eisenhardt, 2010) - we used the FDA classification scheme. The scheme, which is based on specific applications and patient care areas, including cardiology, urology, and gynecology, enabled us to efficiently identify competing device makers in a fine-grained way.

Third, relationships with intermediaries are common in the MIS device sector, and typically considered a precondition for a serious presence in the market. Specifically, MIS device makers rely heavily on venture capital investment to fund the commercialization of new devices, which are expensive (Ackerly et al., 2009). According to our informants, MIS device firms spend three to five years and at least $\$ 40$ million to introduce a new product, and the majority of entrepreneurial firms receive some form of venture capital funding.

In exchange for providing financial capital, VCs typically take an equity stake and may serve on the company's board. VCs also maintain intimate multiyear relationships with their portfolio companies that entail frequent interactions and communications (Garg, 2013; Sahlman, 1990). Our informants described venture capital as "an intermediary function" that "enables innovative ideas to move." Interactions between VCs and portfolio companies tend to be characterized by a free flow of information, as VCs use connections, advice, and coaching to help their portfolio companies innovate more effectively.

Several venture capitalists and entrepreneurs have acknowledged the phenomenon of VC investments in competing entrepreneurial companies. "It's often that we will see startups that seek our support that are competitive with our existing portfolio companies," one venture capitalist said. "I've seen plenty of [VCs], big and small, fund direct competitors" (Sabet, 2011). Another acknowledged the drawbacks of the situation: "When a VC invests in competitive companies, it's like an open marriage. It sounds all well and good, but it's going to create problems down the road" (Wilson, 2007). A further entrepreneur provided this specific insight: "At my startup, our investors had a competitive company in their portfolio. I never knew whose interest my board members were looking out for" (Wilson, 2007).

Our background interviews shed light on the nature of the information that flows through these network ties. Specifically, our informants emphasized the centrality of designing effective products and getting them approved for sale in the market. Accordingly, any information related to these two tasks was seen as valuable and strategically useful for MIS device makers. As one industry expert put it, "What is being leaked is product design and regulatory information," an assertion confirmed by other industry observers. Our informants provided 
illustrative examples of such information flows. First, MIS device startups usually begin with an initial prototype that then evolves significantly over time, often in response to investors' input. "[Investors] can try to redirect or influence the direction where a company is going or the ideas that they have," said one former entrepreneur. Investors also mentioned their regulatory experiences with portfolio companies, which they could draw on to improve another portfolio firm's chances of winning FDA approval. Some suggested that redirecting regulatory information could help some startups at the expense of others. As one put it, "[VCs] work with 20 companies, and they're reselling what they've learned from other companies to the new company." Emphasizing such information's strategic importance, one unsuccessful entrepreneur said, "You can be just slightly off and fail miserably, but, in doing so, you can leave fertile soil for those who follow with simple, perhaps more on-target, settings." Jointly, these insights illustrated the nature of the information that passes between competitors via their shared intermediaries.

Our interviews also revealed that, although the MIS sector is recognized by practitioners, industry analysts, and the FDA as a distinct segment of the medical device industry, it is not captured by Standard Industrial Classification codes or other standardized categorization systems. To avoid sampling on the dependent variable, we utilized a broad-based approach to identify all entrepreneurial firms in the sector. First, we used survey data from a medical device-industry intelligence firm, Windhover Information, to identify firms in the sector. Second, we gathered membership lists and conference proceedings from trade organizations associated with the MIS sector, such as the American College of Surgeons, the International Society for Minimally Invasive Cardiac Surgery, the Medical Device Manufacturers' Association, and the Association for the Advancement of Medical Instrumentation. Finally, we utilized the National Institutes of Health's Medical Subject Heading (MeSH) classification scheme. ${ }^{6}$ $\mathrm{MeSH}$ helped us identify keywords related to MIS devices and procedures based on their usage in medical publications. We then searched LexisNexis and Google for firms that used these words in their business or product descriptions. Two researchers coded basic information on firms found using these methods.

\footnotetext{
${ }^{6}$ See http://www.nlm.nih.gov/pubs/factsheets/mesh.html.
}

We then checked that this initial set of firms met our sample criteria by verifying that each had attempted to develop a MIS device, was based in the United States, was founded between 1986 (the date when the first minimally invasive procedures were performed) and 2007, and had received funding from a VC. To verify that a firm met the sample criteria, we used LexisNexis, the firm's website (when possible), the Who Owns Whom: North America catalog (published by GAP Books with Dun \& Bradstreet), LexisNexis's directory Corporate Affiliations, Thomson Financial's VentureXpert, and VentureSource (Dow Jones). This approach yielded 147 unique MIS device firms, which represents the entire population of VC-backed, U.S.-based startups in this sector during the period. ${ }^{7}$ Because our data are longitudinal, we analyzed our sample as 1,400 firm-years. Firm exits before 2007 resulted from bankruptcy, acquisition, or going public.

\section{Measures}

Dependent variable. We define "innovation" as a process that begins with a new idea or novel invention and "results in the introduction of a new product, process, or service to the marketplace" (Edwards \& Gordon, 1984: 1; Katila \& Shane, 2005). Accordingly, innovations constitute useful, commercialized products, which we measure by means of a yearly count of FDA approvals of devices received by each MIS firm (product introductions). We used the FDA's Premarket Notification and Premarket Approval databases to identify the 734 approvals in our sample. FDA approval is the most appropriate measure of innovation in this sphere because medical devices cannot be sold in the United States without it (Chatterji, 2009; Smith \& Shah, 2013; Wu, 2013). Supporting this view, our informants agreed that FDA approval is the strongest predictor of commercial success in the MIS

\footnotetext{
${ }^{7}$ In supplementary analyses, we examined the entire population (198 firms) of U.S.-based MIS device startups founded between 1986 and 2007, including those that were not VC-backed. Given the substantial capital required to start an MIS firm, we reasoned that firms that did not raise any VC funding were unlikely to have a serious presence in the market and were likely less promising or were of lower quality (Ferrary \& Granovetter, 2009). Comparing VCbacked to non-VC-backed firms, we found differences consistent with that inference, as non-VC-backed firms produced fewer patents and received significantly less total funding on average than VC-backed firms.
} 
device sector. ${ }^{8}$ All the approvals in our sample were for devices categorized by the FDA as "class III" devices, due to their technological complexity and potential risk to patients; such devices undergo the highest level of regulatory scrutiny.

Independent variables. Our primary independent variable captured whether a firm in our sample had indirect ties to its competitors through a shared VC investor; the variable was highly positively skewed, however, so we took the natural logarithm before inclusion in our regression models. ${ }^{9}$ For the subset of firms that had such ties, we determined their number, the sequence of tie formation, the relative commitment exhibited by the shared intermediary, geographic proximity to the intermediary, and the intermediary's status and reputation.

To measure competition, we utilized a comprehensive industry schema presented in Frost \& Sullivan's (2008) U.S. Medical Devices Market Outlook, whose detailed market segmentation by application area (e.g., cardiology, neurology, etc.) mirrors the regulatory panels utilized by the FDA and validated by our industry informants. This schema specifies representative procedures and device types for each industry segment, making it an ideal resource for identifying and categorizing firms. Table 1 provides an overview of market segments and representative types of devices. We hand-coded the firms in our sample, assigning each to as many as four competitive subsegments. We considered two firms to be competitors if they belonged to the same primary subsegment of the MIS device sector. Two separate researchers coded each firm's subsegments as primary through quaternary based on the description of its activities in FDA applications that were subsequently approved. MeSH keywords associated with each competitive subsegment were also used to assign firms (Chai \& Flemming, 2011). The inter-coder reliability rating was $94 \%$. When the coders disagreed,

\footnotetext{
${ }^{8}$ We also explored alternative measures. First, we considered a measure of product introduction success based on the FDA's speed to approval of product applications. The results, consistent with our main analyses, are described in the Additional Analyses section of this paper. Second, we sought to develop a success rate measure to capture effectiveness at getting products approved, but "FDA policies prohibit the release of data on unapproved products" (Hines, Lurie, Yu, \& Wolfe, 2010); we approached the FDA, but were told that they did not collect it.

${ }^{9}$ Before logging this variable, we added .01 to it to ensure that the logged versions of indirect competitor ties would be defined. Substituting values such as .001 or 1 does not substantively alter our results.
}

a third researcher recoded the firms in question. Our sample consisted of 12 competitive subsegments (Table 1).

We then used data from the VentureSource and VentureXpert databases to identify the VC investors for these MIS device firms for the entire period under study (Kaplan, Sensoy, \& Strömberg, 2002). With these data, we created yearly bipartite networks of firms and VC investors in which a tie between a firm and an investor in a given year indicated that the firm received funding from that VC. We constructed these networks so that ties between firms and investors persisted for three years. ${ }^{10}$ From these networks, we then constructed our final count variable, indirect ties to competitors, as the number of unique competitors with which a firm shared a VC investor in a given year (we logged the measure to reduce skew and added a constant of 0.01 prior to logging to account for situations with 0 indirect ties to competitors). ${ }^{11}$

For the subset of firms that had indirect ties to competitors, we considered how many they had, the sequence of formation, the relative commitment exhibited by the shared intermediary, geographic proximity to the VC intermediary, and the status and reputation of the VC intermediaries. First, our logic for initial investment of an indirect tie (Hypothesis 2) suggests that a focal firm that received funding from VC investors before these same investors made any subsequent investments in the focal firm's competitors would be particularly naïve about the potential for leakage and less careful to guard against possible information outflows. Consistent with this binary logic, we constructed earliest shared VC tie as a dummy variable. For a given year, we

\footnotetext{
${ }^{10}$ Prior research suggests that VCs remain actively involved with firms between investment rounds, which typically occur every 1-3 years (Guler, 2007). In sensitivity tests, we considered ties lasting 1-5 years with no substantial change in the results. We did not include the current year in the 3-year window to avoid reverse causality.

${ }^{11}$ We also estimated our models using an untransformed version of this variable, which was not significant. This indicated that the relationship between indirect competitor ties and product introductions was non-linear, even though it was monotonically negative. Because of better model fit in using the log-transformed variable, we report our models with the logged version of the variable. Overall, this robustness test indicated that initial indirect competitor ties have larger negative effects than do subsequent ties-an effect that is consistent with our theory.
} 
TABLE 1

Summary of Medical Device Subsectors ${ }^{\mathrm{a}}$

\begin{tabular}{llr}
\hline \multicolumn{1}{c}{ Subsector name } & \multicolumn{1}{c}{ Representative devices } & No. of firms in sample \\
\hline Cardiology & Pacemakers, cardiac ablation & 67 \\
Disinfection and sterilization & Automatic endoscope reprocessors & 3 \\
Endoscopy & Enteroscopy, choledochoscope & 36 \\
General surgery & Harmonic scalpels, thermal ablation & 45 \\
Hearing and audiology & Nasal sinoscope, laryngoscope & 2 \\
Neurology & Vagus nerve stimulation & 11 \\
Oncology & Volumetric pumps & 5 \\
Ophthalmology & Cataract surgery & 5 \\
Orthopedics and mobility aids & Spinal fixation devices, vertebroplasty & 26 \\
Respiratory and anesthesia & Bronchoscope & 8 \\
Urology & Permanent urethral stents \\
Wound care & Protein-based tissue sealants & 9 \\
\hline
\end{tabular}

${ }^{a}$ Firms can be classified in more than one subsector.

considered the set of all of a focal firm's VC investors that had also invested in its competitor firms. We code this variable equal to " 1 " if the focal firm was ever the first to receive investment out of its competitors from any of the shared VCs. The variable was equal to " 0 " if the firm was not the first to receive investment from at least one of its VCs that had also invested in a competitor, or if none of the firm's VC investors invested in any competitors. ${ }^{12}$

For the relative commitment exhibited by shared intermediaries (Hypothesis 3), our logic suggests that this operates at the level of the focal firm-VCcompetitor triad-that is, the commitment of a shared VC to a focal firm versus a given competitor. Accordingly, we constructed relative commitment from shared $V C$ as a continuous measure that averaged the relative commitment across each of these triads. We operationalized commitment of a VC to a given firm as the number of rounds a VC has funded the focal firm (Guler, 2007). To create this variable, consider a focal firm $F$, which shares an

\footnotetext{
${ }^{12}$ As a robustness test, we also constructed a variant of earliest shared VC tie using a continuous measure that was equal to the proportion of a focal firm's VC investors that invested in the focal firm before investing in any of its competitors. This alternative continuous variable tested whether a firm's "naïveté" was unique for each VC they shared with competitors. While the interaction was negative (similar to the reported measure), it was not statistically significant. We interpreted this non-significance to indicate that, consistent with our logic, a focal firm is particularly vulnerable when indirect competitive ties develop after its VCs have made their initial investments in the focal firm.
}

indirect tie with a competitor $C_{i}$ through a shared investor $j$. To calculate how committed F's ties are to its investors relative to all of its competitors who also share those same investors, we used the following formula (where $n=$ total number of $C_{i j}$ pairs):

$\frac{\sum_{i, j} C_{i j}}{n}$

$C_{i j}=\left\{\begin{array}{l}1 \text { if } F \text { received more rounds of funding from } j \text { than } C_{i} \\ 0 \text { if } F \text { received the same number of rounds from } j \text { as } C_{i} \\ -1 \text { if } F \text { received fewer rounds of funding from } j \text { than } C_{i}\end{array}\right.$

If this value is positive, $F$ has more committed ties to shared investors on average than its competitors; if negative, $F$ 's ties to shared investors are on average less committed than its competitors'; if $0, F$ 's shared investors have a balanced level of commitment to $F$ and its competitors.

We created the continuous variable, relative distance to shared VC (Hypothesis 4), in a similar fashion. First, following Sorenson and Stuart's (2001) approach, we calculated the distance between the center of each firm's zip code and that of each of its investors. Using these calculations, we used an approach similar to Equation (1): if focal firm $F$ is geographically closer to a shared investor than a competitor $C_{i}$, then $C_{i j}$ is -1 ; if $F$ is farther than $C_{i}, C_{i j}$ receives a value of 1 ; if their distance from the investor is identical, $C_{i j}$ is 0 . Here, positive mean values indicate that $F$ is, on average, farther from shared investors than its competitors; negative mean values indicate that $F$ is, on average, nearer to shared investors than its competitors. 
In our analysis, we also included a dummy variable, high-status $V C$, to indicate whether a firm received an investment from a high-status venture capital investor (Hypothesis 5). To assess status, we calculated the VC's eigenvector centrality within investment syndication networks in high-technology industries (Hochberg, Ljungqvist, \& Lu, 2007; Katila et al., 2008). We confirmed that VC status was consistent over time and verified our list of high-status VCs with industry participants. We included a dummy variable for the top 30 VCs in our sample in terms of centrality score; we chose 30 as the cutoff (rather than fewer firms) so as to include VCs that were central in geographies outside Silicon Valley and Boston.

Finally, we utilized Lee et al.'s (2011) yearly index of VC reputations to construct a variable, average $V C$ reputation index, for the average reputation score of the VC investors that a focal firm shares with its competitors (Hypothesis 6). This index assigned yearly reputation scores ranging from 0 to 100 based on their investment histories. ${ }^{13}$

Control variables. We included several control variables to account for firm-specific characteristics and other factors previously shown to affect innovation. We included a control for the firm's age in years, firm age, and a categorical variable for the firm's regional location, region (including regions with established medical device sectors). ${ }^{14}$ We also included a categorical variable for the focal firm's primary subsector (as defined in Table 1). This variable, subsegment category (entered into our models as dummy variables), controlled both for the pool of potential competitors that a firm might be indirectly tied to and for a subsegment's specific dynamics. We also controlled for total funding adjusted, or the total inflation-adjusted dollars received by a firm, and for the total number of a firm's investors, number of total investors, in a given year because increased access to resources benefits innovation (Hall, 2002).

In addition, we controlled for other relationships between firms that might serve as alternative pathways for information flows. First, we controlled for knowledge that could be leaked between firms by including the average number of patents held by the

\footnotetext{
${ }^{13}$ In our data, 121 firm-years contained VCs that were not listed on Lee et al.'s (2011) VC reputation index. Dropping these firm-years did not significantly affect our results for other hypotheses.

${ }^{14}$ Region categories were (1) Boston, (2) Minneapolis, (3) Bay Area, (4) Orange County, (5) New York/New Jersey/ Connecticut, and (6) other. These regions encompass all U.S. regions with established medical device sectors.
}

competitors indirectly tied to the focal firm, mean number of patents held by competitors. Second, we controlled for number of ties to non-competitors because variation in a firm's indirect ties to competitors might simply reflect an investor's tendency to make many investments; we added .01 to each value and then logged this variable to reduce skew. Third, we gathered data from the Thomson Reuters SDC database to generate a count variable for a focal firm's number of alliances to competitors (direct ties) in a given year. ${ }^{15}$ In addition, we controlled for the number of patents applied for that were subsequently granted by a firm in a given year as an indicator of its technical resources. We also included a one-year lagged patent variable in our models to control for the focal firm's invention output in the recent past. Data for these controls came from firm websites, archive.org, the U.S. Patent Office, the National Bureau of Economic Research (NBER) patent database, ZoomInfo, and the Corporate Technology Directory.

\section{Statistical Methods and Estimation}

Our outcome variable, the number of product introductions, was a count variable. We used zeroinflated (ZIP) Poisson regression because we observed 0 product introductions for $79.7 \%$ of our firm-years. Our models included random effects for firms to control for unobserved between-firm variation and dummy variables for year to control for factors that vary over time but not by firm. ${ }^{16} \mathrm{We}$ estimated these models using the glmmADMB

\footnotetext{
${ }^{15}$ Although we report models that include alliances with competitors, we also ran models that considered all alliances to any firm in the industry. Our results did not change.

${ }^{16}$ We preferred firm-level random effects to firm-level fixed effects in our models for several reasons. First, the use of firm-level fixed effects requires the assumption that the between-firm variation captured by these fixed effects are the same from year to year-an assumption not borne out in our data (Certo \& Semadeni, 2006). Second, a Hausman test produced a non-significant test statistic ( $p=.13, d f=2, \chi^{2}$ test), suggesting that our random effects estimates were unbiased and more consistent than our fixed-effects model estimates (Wooldridge, 2002). Finally, our models only rarely converged when using firm-level fixed effects. We attribute this to having little within-firm variation and to zero-inflated Poisson models being unstable under fixed-effects specifications for clustered data like ours (see Min \& Agresti (2005), who recommended random-effects specifications for ZIP models).
} 
package in $\mathrm{R}$, which allowed for the estimation of random effects ZIP models. ${ }^{17}$ Finally, we presented our model estimates with standard errors that were clustered by year and firm (Cameron, Gelbach, \& Miller, 2011).

\section{RESULTS}

Descriptive statistics and correlations appear in Table 2. Our primary independent variable, the number of indirect ties to competitors in a given year, is not highly correlated with our other variables. The high correlation between number of indirect ties to competitors and number of indirect ties to non-competitors ( $r=.71$; see Table 2$)$ is an exception. This is possibly attributable to the observation that firms with a large number of indirect ties to competitors likely receive funding from VCs that are very active in funding companies in general. As a result, these same VCs make investments in many non-competitor firms as well. Our post-estimation model diagnostics indicate, however, that this does not reduce the efficiency of our models, as the average variance inflation factor (VIF) for our independent variables is 3.99 (well below the acceptable maximum threshold of 5). Conditional index scores for our variables were also below 30, indicating that multicollinearity is not a concern in all of our models (with the exception of Model 8 in Table 3, which includes multiple interactions that contain the same component variable that, together, produce an average VIF of 5.8).

According to Table 2, the firms in our sample introduced an average of one product every two years (mean $=0.53$ product introductions per firmyear). In a given year, $53 \%$ of the firms had at least one indirect tie to their competitors. ${ }^{18}$ Our data also reveal that, of the 751 unique VCs in our study, 133

\footnotetext{
${ }^{17}$ Because the standard deviation of our dependent variable exceeds its mean, we also estimated zero-inflated negative binomial (ZINB) versions of our models to account for over-dispersion. In these ZINB models, however, we found that log- $\theta$ parameter, which is included as a covariate to adjust for over-dispersion, was not statistically significant, indicating that over-dispersion does not introduce bias in our ZIP models.

${ }^{18}$ Recall that our measure for having an indirect tie to another firm called for a focal firm and another firm to share the same investor. Our tie-decay window specified that, if an investment tie between a firm and an investor was not renewed within three years and if the firm does not receive funding from the investor again, the tie disappears.
}

$(17 \%)$ backed competing firms. Firms had a mean of 4.23 indirect ties to competitors each year with a standard deviation of 6.99. These values are consistent with our fieldwork, which suggested that VCs tend to specialize, making them likely to fund multiple firms in the same competitive subsegment, creating the potential for leakage between competitors.

Table 3 reports the estimated coefficients of seven zero-inflated Poisson regression models. Model 1 includes our control variables. Model 2 includes the main effects for all of our hypotheses. Model 3 adds a dummy variable for whether the firm was the earliest to receive funding from an investor that also backed its competitors (and its interaction with the number of indirect competitive ties). Model 4 includes our continuous variable for the relative commitment of a firm's ties with its shared investors (and its interaction with the number of indirect competitive ties). In Model 5, we add our measure of a firm's geographic proximity to its shared investors relative to that of its competitors (and its interaction with the number of indirect competitive ties). Model 6 adds the interaction of indirect competitive ties and our dummy variable for whether the shared VC was high status. Model 7 adds a similar interaction with the average reputation index of a firm's venture capital investors. We also estimated a model with all interactions to test their robustness (Model 8).

Because our full model includes multiple interaction terms, each of which contains our main variable-indirect ties to competitors-it is difficult to interpret the variables' coefficients as a conditional effect to evaluate our separate hypotheses using the full model. We therefore refer to the partial models to discuss conditional effects and to the full model as a robustness check, and we point out any discrepancies between the two. And, because we enter the log transformation of indirect ties to competitors, its relationship with our dependent variable, product introductions, is non-linear. Thus, as an example to ease interpretation of our models, we consider how product introductions are affected when indirect ties to competitors increases from 0 to 1 . Figure 1 illustrates the predictions from our models as they relate to our hypotheses.

In Hypothesis 1, we reasoned that entrepreneurial firms with many indirect ties to competitors through a shared investor would be less innovative than firms without such ties. We find support for this hypothesis. The negative and significant coefficient of the indirect ties to competitors variable in Table 3, Model 2, indicates that having just one 


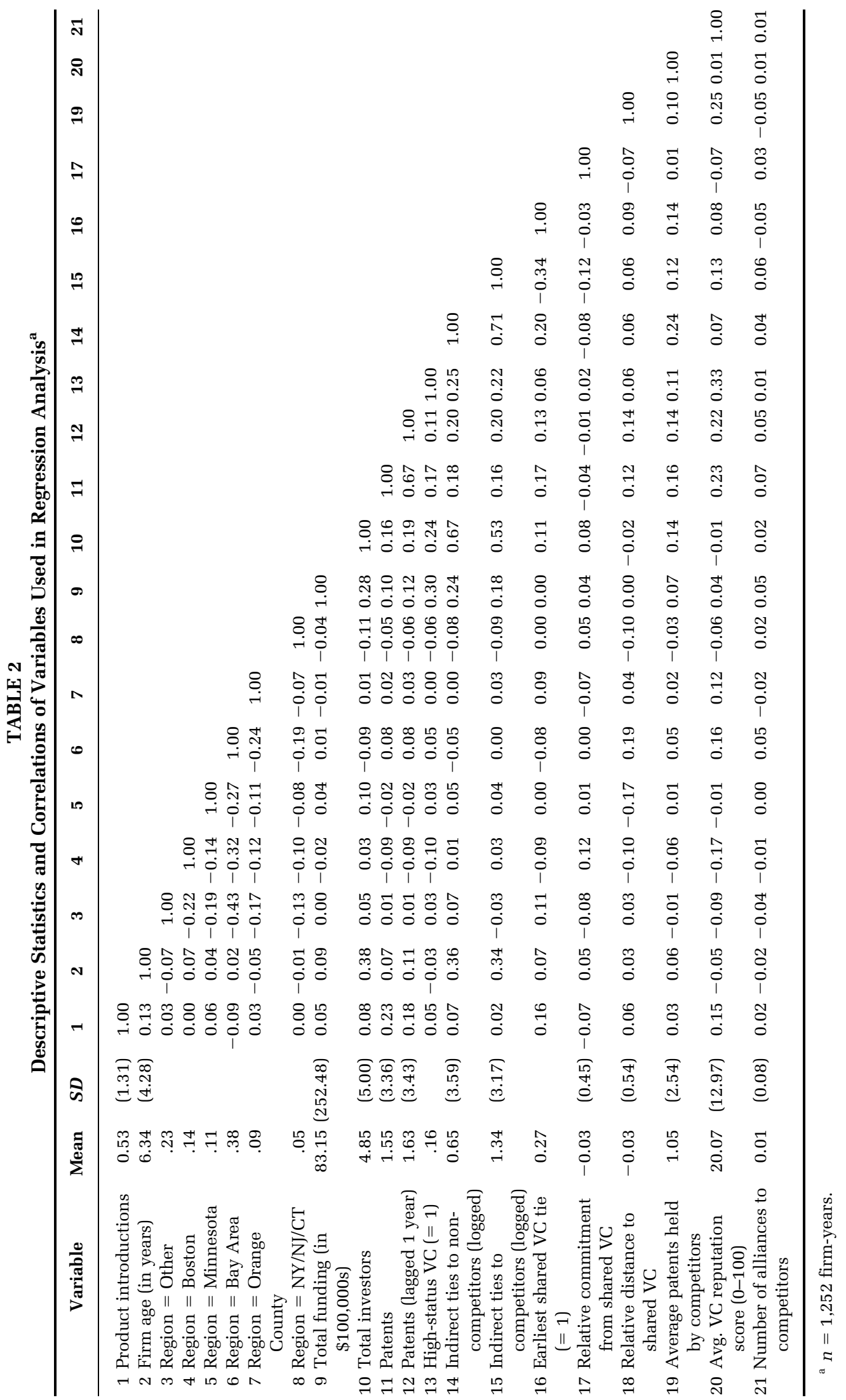


indirect tie to a competitor decreases an MIS device firm's total product introductions by $30 \%$ in a given year $(\exp [(\log (1.01$ tie $)-\log (.01$ ties $)) \times-.076]=.704$, $p<.001$; Table 3, Model 1). ${ }^{19}$

In Hypothesis 2, we asserted that, among entrepreneurial firms with indirect ties to their competitors, those that formed the earliest tie to a shared investor would be less innovative. The coefficient of the interaction term is negative and significant in Model 3 (Table 3), offering support for this hypothesis. The number of indirect ties to competitors has a non-statistically significant impact on product introductions (Table 3, Model 3), unless the focal firm was the first among its competitors to form a tie with a shared investor, in which case having an indirect competitive tie decreases its expected product introductions in a given year by $34 \%$ (exp[(log $(1.01$ tie $)-\log (.01$ ties $)) \times .(-.002-.088)]=.660$; Table 3, Model 3). The same interaction term is not statistically significant in the full Model 8, suggesting partial support. We attribute this finding to the inclusion of the interactions of indirect ties to competitors with several other variables. These interaction effects are highly correlated with one another because they all include indirect ties to competitors. Furthermore, the smaller sample size due to the inclusion of the average-VC-reputation variable likely inflated standard errors but did not meaningfully affect the value of the coefficient of the interaction, which remained negative. This suggests that Model 3 is a more reliable estimate, and that having the earliest tie to a shared investor does indeed undermine innovation.

Through Hypothesis 3, we speculated that, among entrepreneurial firms with indirect ties to their competitors, those with less committed ties to a shared investor would be less innovative than those with more committed ties. The positive and significant interaction term in Table 3 , Model 4, supports this claim. Moving from 0 to 1 indirect competitive tie diminishes a firm's innovation output by $55 \%(\exp [(\log (1.01$ tie $)-\log (.01$ ties $)) \times$ $(-.085+(-1 \times .086))]=.454$; Table 3 , Model 4$)$ if the shared investor is less committed to the focal firm than to its competitor. But, if the shared investor is more committed to the focal firm than to its

\footnotetext{
${ }^{19}$ We do not interpret this variable using Model 7 in Table 3 because Model 1 illustrates the baseline effect of indirect ties to competitors. Because Model 8 contains this variable along with multiple interaction terms that simultaneously include it, we would be observing a conditional effect rather than a baseline effect.
}

competitor, gaining the indirect competitor tie has a negligible positive effect on product introductions $(\exp [(\log (1.01$ tie $)-\log (.01$ ties $)) \times$ $(-.085+(1 \times .086))]=1.005$; Table 3, Model 4). Thus, the negative impact of indirect ties to competitors is felt more strongly by firms whose ties to shared investors are, on average, less committed than their competitors.

In Hypothesis 4, we argued that, among entrepreneurial firms with indirect ties to their competitors, those that are more geographically distant from a shared investor would be less innovative than those that are more proximate. Our results support this hypothesis, too. According to Table 3, Model 5, gaining one indirect competitive tie diminishes product introductions by $56 \%$ if the focal firm is always farther from a shared investor than its competitors (exp[(log $(1.01$ tie $)-\log (.01$ ties $)) \times(-.069+(1 \times-.111))]=.435$; Table 3, Model 5). However, if the focal firm is always nearer than its competitors to the shared investor, gaining the same indirect competitive tie increases product introductions by $21 \%(\exp [(\log (1.01$ tie) $-\log (.01$ ties $)) \times(-.069+(-1 \times-.111))]=1.214$, $p<.01$; Table 3, Model 5).

In Hypothesis 5, we ventured that, among entrepreneurial firms with indirect ties to their competitors, those with high-status investors would be less innovative than those with lower-status investors. The coefficient is significant in the partial model (Model 6) but not in the full model (Model 8), suggesting partial support for this hypothesis. According to Table 3, Model 6, a focal firm experiences $22 \%$ fewer product introductions by gaining an indirect competitor tie $(\exp [(\log (1.01$ tie $)-\log (.01$ ties $)) \times$. $(-.055)]=.776$; Table 3, Model 6) if the focal firm does not receive funding from a high-status VC. But, if the firm has a high-status VC, gaining an indirect competitor tie decreases product introductions even more-by $43 \%(\exp [(\log (1.01$ tie $)-\log (.01$ ties $)) \times$. $(-.055-.068)]=.567$, Table 3, Model 6).

Finally, in Hypothesis 6, we suggested that the reputation of the intermediary would attenuate the negative effect of indirect competitive ties, due to the behavioral tendencies of high-reputation VCs and their incentives to avoid the appearance of untoward behavior. Models 7 and 8 present the partial and full models testing this prediction. It should be noted that a small proportion of firms (121 firmyears out of 1,252 in the regression analysis) lacked VC investors listed in our reputation index. To analyze sample bias, we estimated all of the models in Table 3 drawing on this slightly smaller sample and found no meaningful differences in our results. 


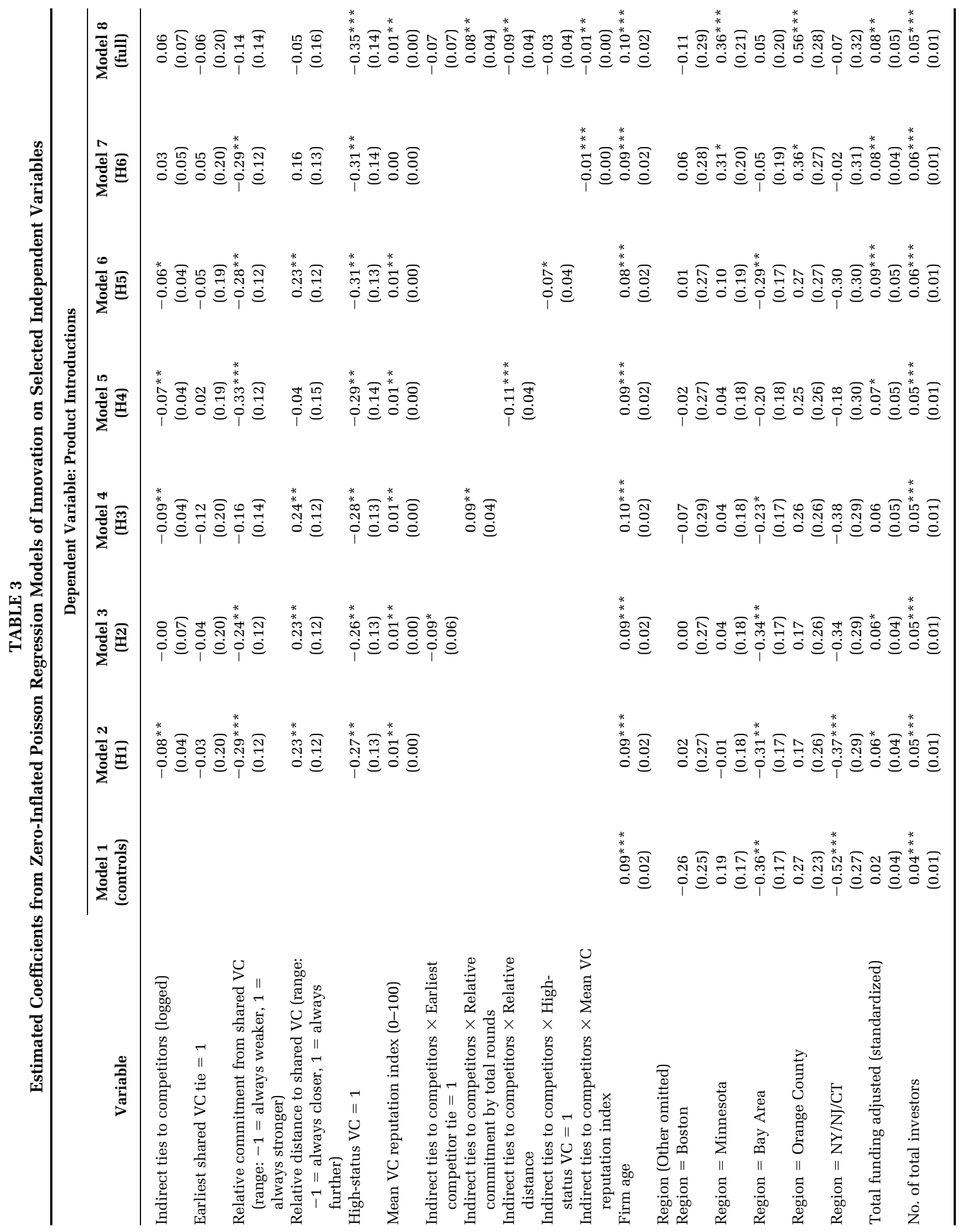




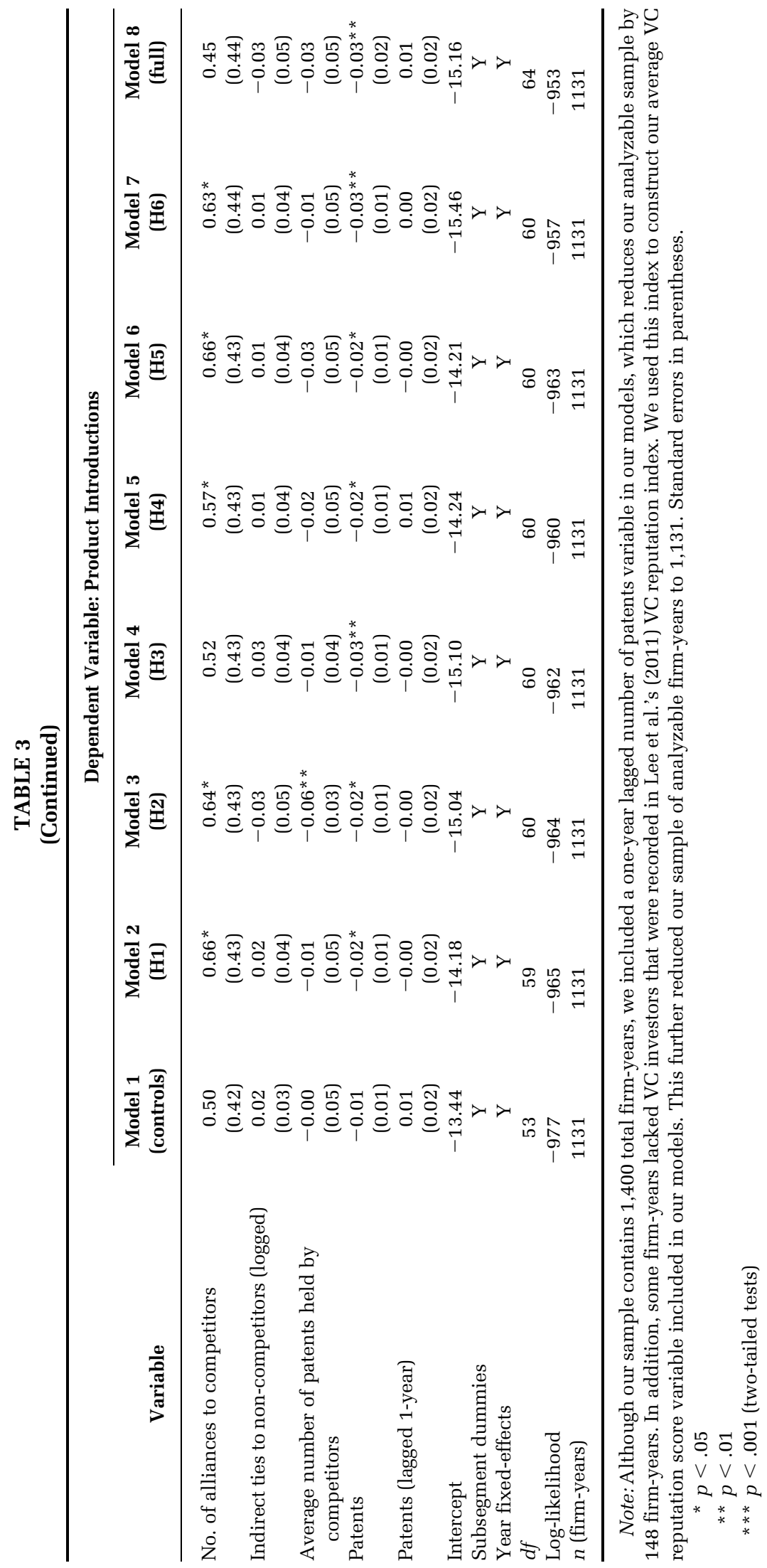


Contrary to expectations, we find a different dynamic in Models 7 and 8 than hypothesized. As depicted in the graph for Hypothesis 6 in Figure 1, high reputation actually exhibits a steeper negative relationship between indirect competitor ties and innovation-and not the flatter relationship that we predicted for high-reputation VCs. For a focal firm funded by VCs with a mean reputation index of 25 (out of 100), adding an indirect competitive tie decreases the firm's product introductions by $35 \%$ $(\exp [(\log (1.01$ tie $)-\log (.01$ ties $)) \times(.032+(-.005 \times$ 25)) $]=0.651$; Table 3, Model 7). However, if the firm's VC funders have a mean reputation index of 75 (out of 100), gaining an indirect competitive tie decreases product introductions by almost $80 \%$ (exp[(log(1.01 tie $)-\log (.01$ ties $)) \times(.032+(-.005 \times 75))]=0.205$; Table 3, Model 7).

What explains this result? The graph for Hypothesis 6 in Figure 1 indicates that having many indirect ties eliminates the benefits of high-reputation VCs. Contrary to our hypothesis, indirect ties to competitors actually moderate the otherwise positive impact of VC reputation. One possible explanation, consistent with this view, is that a VC's willingness to back competing entrepreneurial firms serves as a credible signal that it is prioritizing its own interests over those of its partners-that is, that the VC is of low "character" (Mishina et al., 2012). Accordingly, high-reputation VCs that invest in competing firms may be less willing to aid their portfolio firms, diminishing the benefits of such VCs. We return to this surprising finding in the discussion.

\section{Additional Analyses}

Higher-quality firms are likely to elicit more committed ties from their investors than their competitors, and they are also likely to generate more product introductions. Thus, the positive interaction that we hypothesized between a focal firm's indirect competitive ties and relative commitment may be an artifact of the firm's unobserved quality. According to our interviews, the number of patents held by an entrepreneurial firm is a key indicator that can drive both a VC's willingness to invest and the likelihood that a firm will introduce new products. Indeed, existing research shows that patents are a credible signal of the quality of entrepreneurial firms (Hsu \& Ziedonis, 2013), and that patenting by young firms is especially important in the medical device sector (Cohen, Nelson, \& Walsh, 2000; Graham, Merges, Samuelson, \& Sichelman, 2009). Thus, to better isolate the interaction effect of tie commitment, we ran additional analyses using a subsample of firms that had received funding before they received any patents. By limiting our subsample to such firms, we tested our hypotheses when the quality of the firms in question was largely unknown prior to investment. The results using this more conservative sample were largely consistent with the coefficient estimates in Table 3.

Difference-in-differences analysis. To assess whether endogeneity was affecting our results, we conducted a difference-in-differences (DiD) analysis (see Short \& Toffel (2010) and Bernstein (2012) for similar approaches). Specifically, we wanted to know whether some unobserved factor affects both a firm's likelihood of having indirect competitor ties and its innovation output. We first divided our sample into: (1) treatment-group firms, each of which had at least one indirect tie to a competitor during their time in the period covered by our dataset, and (2) control-group firms, which did not. Moreover, because DiD analyses entail observing behavior before and after a treatment has been applied, we included a firm in the treatment group only if firm-year data existed for at least two years prior to and two years after it received VC funding. For example, if a firm formed an indirect competitive tie in 1994, but our data on it began in 1993, it was not included in the treatment group. After dividing our sample, we matched each treatmentgroup firm to a control-group firm based on year ranges in our data. For example, a treatment-group firm that spanned 1990 to 2000 in our dataset would be matched to a control-group firm that also spanned 1990 to 2000. Matching was also based on firm age, region, and the number of patents held prior to funding, resulting in 420 total firm-years.

We then constructed dummy variables for treatment group (treatment $=$ " 1 ," control $=$ " $0 "$ ") and post-treatment period (pre-treatment $=$ "0," posttreatment $=$ “1"), which we interacted in our DiD models. According to our results, the negative and significant interaction effect between the treatmentgroup dummy and the post-treatment dummy variables $(p<.10)$ suggests that, in the post-treatment period, the treatment-group firms experienced fewer product introductions as a result of having competitive ties. We attribute this marginal significance level to the small sample size necessitated by our matching processes, which made for a conservative analysis. Overall, these findings are consistent with our original results and indicate that indirect competitive ties diminish product introductions. 
FIGURE 1

Predicted Number of Product Introductions Based on Interaction of Logged Indirect Competitor Ties with Selected Variables
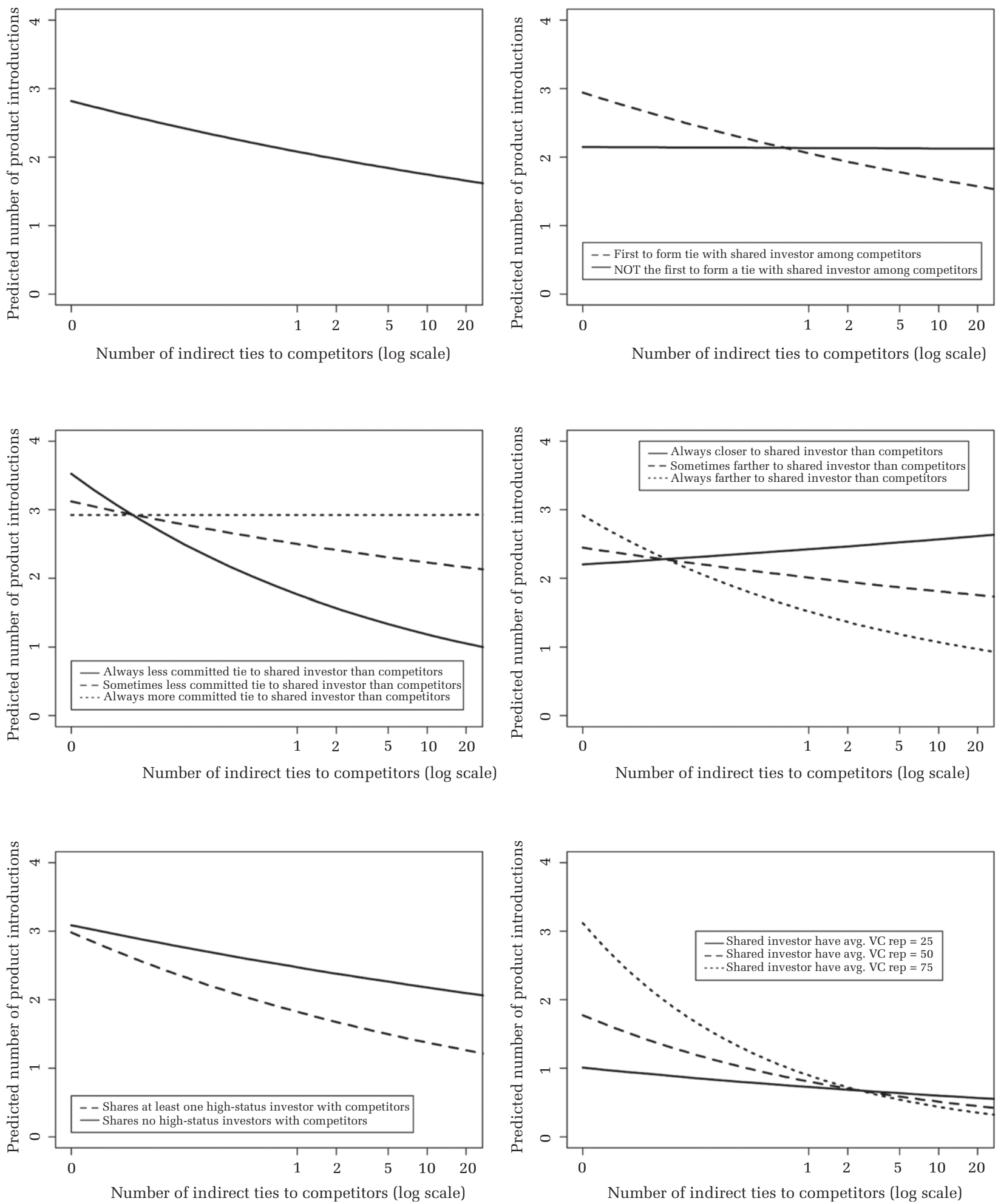
Alternative dependent variable. Although our fieldwork indicated that FDA approval of devices was the most appropriate indicator of commercial success in the sector, there are other ways of measuring innovation success. Because speed to market is an important entrepreneurial outcome (Schoonhoven et al., 1990), we also sought to measure how quickly a firm was able to get through the regulatory approval process. We calculated the length of time between a firm's application to the FDA for each product introduction and approval of the application. For those firms that introduced products, we examined average speed to approval for years in which they had indirect competitive ties and for years in which they did not have such ties. Our analysis indicates that, in the former case, mean speed to approval was approximately four months; in the latter case, it was three months. Thus, having indirect ties to competitors appears to undermine innovation by impeding the process of obtaining FDA approval.

Direct assessment of information flows. We reasoned that, if leakage was indeed occurring via the channels we posited, even if mostly informally, we might find indications of information flow to competitors in firms' formal patent citations. Thus, we collected data from the NBER patent database on interfirm patent citations, which are explicit and formal instantiations of knowledge flows between firms. Of the 3,961 patents held by firms in our sample, each received, on average, about eight citations from other patents in our sample. We then compiled two groups of firm-dyads, each composed of two firms with a common VC investor: the first group consisted of dyads in which the two firms in a dyad were competitors; the second consisted of two firms that were not competitors. We then counted the number of patent citations over time for each firm. For each dyad, we further distinguished between patent citations by before and after they shared a common VC. Our findings indicate that competitor firms cite each other's patents over four times as often after they share an investor as they do before (0.095 vs. 0.023 mean citations). Noncompetitor firms cite each other's patents less than three times as often after sharing an investor as before ( 0.028 vs. 0.010 mean citations). Thus, having a common venture capital investor promotes formal information flow between firms-an effect that is particularly strong for competitors. For the competitors that shared a common VC investor, we performed a similar analysis to probe the impact of initial investment (Hypothesis 2), commitment
(Hypothesis 3), and geographic proximity (Hypothesis 4) of their shared VC ties on information flows using patent citations. Results were consistent with our main results in Table 3.

Overall, our attempts to assess information flows directly are consistent with the logic of our main arguments, but we caution that using patent citations to measure information flows between firms can be subject to bias. They "do not reflect the knowledge that is transmitted via other, typically more private channels" (Roach \& Cohen, 2013: 521). As our qualitative data demonstrate, much of the information leaked between portfolio firms appears to be exchanged informally. We treat our patent citation analysis as merely complementary evidence.

\section{DISCUSSION}

This study examines the impact of relationships with intermediary organizations on innovation at new firms. Focusing on entrepreneurial firms and their venture capital investors, we considered the indirect ties that arise among competitors that share the same intermediary, their VC investor. In building a theory of competitive information leakage via indirect ties, we conceptualized how and why powerful intermediaries might redirect important information the spread of which could negatively impact some entrepreneurial firms. Using a dataset consisting of 22 years of product introductions and patents in the U.S. MIS medical device sector, we tested our theory and found broad support for its predictions in two areas. First, firms that have many indirect ties to competitors via a shared intermediary are less innovative than those with few ties (or none). Second, several factors related to an intermediary's opportunities and motivation to leak information moderate this relationship. Overall, our study extends network perspectives on innovation and contributes to research on strategic entrepreneurship.

\section{Indirect Ties, Intermediaries, and Information Leakage}

Our study contributes to research on interfirm relationships and innovation with an emphasis on entrepreneurial firms. Though prior work has often extolled the virtues of network ties for innovation, especially for young firms (Baum et al., 2000; Ozcan \& Eisenhardt, 2009; Stuart, 2000), we motivated a common scenario inconsistent with the assertion that network relationships promote innovation, and marshaled new theory and empirical evidence to 
study the scenario further. Our study joins a growing body of research on the negative consequences of networks for entrepreneurial firms (Maurer \& Ebers, 2006; Stam \& Elfring, 2008; Vissa, 2012).

Our primary contribution is to elucidate an alternative pathway and attendant mechanism whereby network relationships negatively impact young firms. Prior research on the negative consequences of relationships has primarily focused on direct ties between firms (Diestre \& Rajagopalan, 2012; Katila et al., 2008; Vissa \& Chacar, 2009). In contrast, we explored how indirect ties created at the discretion of powerful intermediaries can have negative outcomes for young firms by leading to competitive information loss. By identifying direct competitors, we showed that having many indirect relationships with competitors can be detrimental to innovation. Our results recast prevailing perspectives on networks and innovation, which imply that innovation is an inherently collaborative endeavor and that firms gain advantages from being embedded in a rich network of ties and interfirm relationships (Powell et al., 1996). Moreover, compared to the few innovation studies that demonstrate the innovation benefits of indirect ties (Ahuja, 2000; Zhang \& Li, 2010), our conceptualization specifies the conditions under which powerful intermediaries exploit such ties at the connected firms' expense.

We also theorized a new mechanism whereby network relationships can negatively impact young firms. Specifically, we looked at the effect of indirect ties on information outflows, whereas prior research has focused on barriers to knowledge inflows. Past studies have tended to view a network's negative effects on performance in terms of constraints imposed by over-embeddedness, implying that important economic activities are stifled when too many embedded ties prevent firms from accessing novel information (Elfring \& Hulsink, 2003; Stam \& Elfring, 2008; Uzzi, 1997). In contrast, our theory and results suggest conditions under which information leakage leads to negative outcomes. The theoretical implications of this phenomenon suggest a need for heightened sensitivity to the dual nature of information exposure and perhaps for restricted access to information that can benefit a competitor.

\section{Intermediary Contingencies and Network Effects}

Entrepreneurship researchers have framed relationship formation as a strategy whereby entrepreneurial firms can overcome the "liability of newness" (Baum et al., 2000; Stinchcombe, 1965). Like others, we have taken issue with this perspective and asked under what conditions early relationships might actually inhibit innovation efforts. Focusing on entrepreneurs' early investment relationships with investors, and building our arguments from both the network perspective and the competitive exposure perspective, we identified a set of contingencies that point to significant drawbacks of these relationships.

Our secondary contribution is outlining when indirect ties to competitors can be expected to be more or less detrimental to innovation. Thus, though prior network studies have examined how characteristics of the focal firm, network composition, and environment shape network effects (Gulati et al., 2011; Phelps, 2010; Shipilov, 2006), our study extends the contingency perspective further by identifying the important characteristics of the intermediaries that broker the indirect relationship. We argue that certain characteristics provide intermediaries the opportunity, motivation, and ability to redirect information flows to benefit some firms (and the intermediaries themselves) at the expense of others. Our results are consistent with venture capitalists' redirection of information from young firms whose relationships with them are the earliest formed, less committed, and geographically distant; they also suggest that highstatus venture capitalists are especially able (and willing) to leak competitive information that harms firms while amplifying the skewed distribution of their own economic returns.

Our findings are also consistent with a growing body of research that highlights the differences between organizational status and reputation. Specifically, we provide some tentative support to our argument that status is more likely than reputation to be associated with untoward behaviors arising from a high-power position. More broadly, our theory and evidence point to the critical role of intermediaries and indirect ties in inhibiting young firms. Overall, our study suggests that some network ties have the potential to make new firms even more vulnerable-a potential issue that we refer to as competitive leakage.

\section{Managerial Implications}

Our study may be useful for entrepreneurs and venture capitalists navigating early investment relationships. We began this paper with an empirical example of two competing firms sharing the same venture capital investor. To return to that case, 23andMe had the earliest investment relationship 
with Mohr Davidow, and was therefore more vulnerable to leakage; its competitor Navigenics was well positioned to take advantage of leakage. Recent research suggests that established firms engage in network maintenance to enhance innovation from collaborations (Davis, 2011) and to mitigate competitive exposure through indirect ties (Hernandez et al., 2014), but such options may not be viable for resource-constrained ventures. From a normative standpoint, our results thus indicate that entrepreneurs might do well to view VCs as "a necessary evil" (as one entrepreneur put it) and to avoid investors that back direct competitors.

Our study also suggests that "don't go it alone" (Baum et al., 2000) may be overly simplistic advice for entrepreneurs. Not all relationships are beneficial, and entrepreneurs should carefully scrutinize prospective investment partners. As one prominent venture capitalist argued, "What you want is to work with investors who will always be doing what's best for the company, not what's best for them." VCs that simultaneously invest in competitors signal their low character, and entrepreneurs should be cautious about engaging them. If entrepreneurs choose to work with investors who back competitors, they can protect themselves by pursuing later-formed, more committed, and more geographically proximate relationships with venture capitalists and by guarding against information outflows that could be "resold" to competitors.

Of course, our results have different implications for intermediaries. Because they seek to maximize economic returns, venture capitalists should consider backing competitors in the same sector to develop expertise and channel information to "home-run" candidates so as to amplify the skewed distribution of returns. High-reputation investors are partially constrained by prior actions, but high-status investors may have no qualms about leaking information.

\section{Limitations and Future Research}

Our study's limitations present several encouraging avenues for future research. One stems from the drawbacks of our single-industry design. A detailed analysis of one industry subsector and one type of intermediary organization (venture capitalists) is insufficient to fully generalize our theory. Future research may profitably explore other indirect ties (such as client relationships) (Rogan \& Sorenson, 2014) arising through different intermediary organizations that serve competitors (such as consulting firms) (Semadeni, 2001; Thomke \& Nimgade, 2000) to determine whether the leakage mechanism we posit operates in the same detrimental way. The "winner-takes-all”-like dynamics we identified align well with the negative impact of information leakage on innovation, but leakage is only one among many threats to new firms and may be less important in sectors that exhibit less stark competitive interdependence.

A second opportunity emerges from our inability to observe information leakage directly. We have done our best to rule out alternative explanations for the negative impact of indirect ties on innovation, and have provided additional illustrative evidence from supplemental quantitative analysis (e.g., patent citations) and fieldwork. However, the evidence from our qualitative interviews can only point to leakage, and it was not systematically collected across the study window. Future researchers may employ alternative methodologies to more richly document the nuances of the leakage mechanism and to connect them to an intermediary's motivations to redirect information flows (e.g., see the interplay between Mansfield's (1985) examination of leakage effects and von Hippel's (1987) observation of the mechanism itself).

A third opportunity arises from not distinguishing empirically between the possibility of information transfer and its successful execution (Phelps, Heidl, \& Wadhwa, 2012; Wang, 2015). We observed innovation outcomes, inferring that successful information transfer (leakage) had occurred, but we assumed that useful information was passed. Future research should more carefully unpack the stages of information transfer due to leakage, scrutinize the causal chain of information flow from sources to competitors via intermediaries, and delve into the implications of non-useful or distorted information being passed through networks (Schilling \& Fang, 2013).

\section{CONCLUSION}

This study has important implications for theory about how entrepreneurial firms successfully navigate early relationships with partners. By focusing on indirect ties to competitors, we shed light on an insidious pathway for information leakage and offer a richer perspective on the actions of powerful intermediaries to redirect information flows and to orchestrate-and, at times, to undermine-entrepreneurial innovation.

\section{REFERENCES}

Abrahamson, E. 2006. Global ideas: How ideas, objects, and practices travel in the global economy. 
Barbara Czarniawska \& Guje Sevón, eds. Administrative Science Quarterly, 51: 512-514.

Ackerly, D. C., Valverde, A. M., Diener, L. W., Dossary, K. L., \& Schulman, K. A. 2009. Fueling innovation in medical devices (and beyond): Venture capital in health care. Health Affairs, 28: w68-w75.

Ahuja, G. 2000. Collaboration networks, structural holes, and innovation: A longitudinal study. Administrative Science Quarterly, 45: 425-455.

Barron, D. N., \& Rolfe, M. 2012. It ain't what you do, it's who you do it with: Distinguishing reputation and status. In M. L. Barnett \& T. G. Pollock (Eds.), Oxford handbook of corporate reputation: 160-178. Oxford, UK: Oxford University Press.

Baum, J. A. C., Calabrese, T., \& Silverman, B. R. 2000. Don't go it alone: Alliance network composition and startups' performance in Canadian biotechnology. Strategic Management Journal, 21: 267-294.

Benson, D., \& Ziedonis, R. H. 2009. Corporate venture capital as a window on new technologies: Implications for the performance of corporate investors when acquiring startups. Organization Science, 20: 329-351.

Bernstein, E. S. 2012. The transparency paradox: A role for privacy in organizational learning and operational control. Administrative Science Quarterly, 57: 181-216.

Boudreau, K., Lakhani, K., \& Lacetera, N. 2011. Incentives and problem uncertainty in innovation contests: An empirical analysis. Management Science, 57: 843-863.

Burt, R. S. 1999. Entrepreneurs, distrust, and third parties: A strategic look at the dark side of dense networks. In J. M. Levine, L. L. Thompson, \& D. M. Messick (Eds.), Shared cognition in organizations: The management of knowledge: 213-144. Mahwah, NJ: Lawrence Erlbaum Associates, Inc.

Burt, R. S. 2001. Bandwidth and echo: Trust, information, and gossip in social networks. In J. E. Rauch \& A. Casella (Eds.), Networks and markets: 30-74. New York: Russell Sage Foundation.

Cameron, A. C., Gelbach, J. B., \& Miller, D. L. 2011. Robust inference with multiway clustering. Journal of Business \& Economic Statistics, 29: 238-249.

Certo, S. T., \& Semadeni, M. 2006. Strategy Research and Panel Data: Evidence and Implications. Journal of Management, 32: 449-471.

Chai, S., \& Flemming, L. 2011. Emergence of breakthroughs: A case study of RNA interference. (Working Paper, Harvard Business School). Paper presented at the DIME-DRUID Academy Winter Conference 2011, Comwell Rebild Bakker, Aalborg, Denmark, January 20-22, 2011.

Chandler, D., Haunschild, P. R., Rhee, M., \& Beckman, C. M. 2013. The effects of firm reputation and status on interorganizational network structure. Strategic Organization, 11: 217-244.

Chatterji, A. K. 2009. Spawned with a silver spoon? Entrepreneurial performance and innovation in the medical device industry. Strategic Management Journal, 30: 185-206.

Chen, E. L., Katila, R., McDonald, R., \& Eisenhardt, K. M. 2010. Life in the fast lane: origins of competitive interaction in new vs. established markets. Strategic Management Journal, 31: 1527-1547.

Chen, M. J. 1996. Competitor analysis and interfirm rivalry: Toward a theoretical integration. Academy of Management Review, 21: 100-134.

Chena, H., Gompers, P., Kovner, A., \& Lerner, J. 2010. Buy local? The geography of venture capital. Journal of Urban Economics, 67: 90-102.

Cohen, W. M., Nelson, R. R., \& Walsh, J. P. 2000. Protecting their intellectual assets: Appropriability conditions and why U.S. manufacturing firms patent (or not) (NBER Working Paper). Cambridge, MA: National Bureau of Economic Research.

Cumming, D., \& Dai, N. 2010. Local bias in venture capital investments. Journal of Empirical Finance, 17: 362-380.

Davis, J. P. 2011. Network agency problems: Reconceptualizing brokerage as a barrier to embedded relationships (Working Paper, INSEAD). Fontainebleau, France: INSEAD.

Diestre, L., \& Rajagopalan, N. 2012. Are all "sharks" dangerous? New biotechnology ventures and partner selection in R\&D alliances. Strategic Management Journal, 33: 1115-1134.

Dimov, D., \& De Clercq, D. 2006. Venture capital investment strategy and portfolio failure rate: A longitudinal study. Entrepreneurship Theory and Practice, 30: 207-223.

Dushnitsky, G., \& Shaver, J. M. 2009. Limitations to interorganizational knowledge acquisition: The paradox of corporate venture capital. Strategic Management Journal, 30: 1045-1064.

Edelman, B. G. 2014. Mastering the intermediaries: Strategies for dealing with the likes of Google, Amazon, and KAYAK. Harvard Business Review, 92: 86-92.

Edmondson, A. C., \& McManus, S. E. 2007. Methodological fit in management field research. Academy of Management Review, 32: 1246-1264.

Edwards, K., \& Gordon, T. 1984. Characterization of Innovations Introduced on the US Market in 1982. Washington, DC: The Futures Group and U.S. Small Business Administration.

Elfring, T., \& Hulsink, W. 2003. Networks in entrepreneurship: The case of high-technology firms. Small Business Economics, 21: 409-422. 
Ertug, G., \& Castellucci, F. 2013. Getting what you need: How reputation and status affect team performance, hiring, and salaries in the NBA. Academy of Management Journal, 56: 407-431.

Ferrary, M., \& Granovetter, M. 2009. The role of venture capital firms in Silicon Valley's complex innovation network. Economy and Society, 38: 326-359.

Festinger, L., Schachter, S., \& Back, K.1950The spatial ecology of group formation. In L. Festiger, S. Schachter \& K. Back (Eds.), Social pressure in informal groups: 146-161. Stanford, CA: Stanford University Press.

Fombrun, C., \& Shanley, M. 1990. What's in a name? Reputation building and corporate strategy. Academy of Management Journal, 33: 233-258.

Frost \& Sullivan. 2008. U.S. medical devices market outlook, 2008 (Market Report N1A5-01). New York: Frost \& Sullivan.

Gaba, V., \& Terlaak, A. 2013. Decomposing uncertainty and its effects on imitation in firm exit decisions (Working Paper, INSEAD). Fontainebleau, France: INSEAD.

Garg, S. 2013. Venture boards: Distinctive monitoring and implications for firm performance. Academy of Management Review, 38: 90-108.

Gifford, S. 1997. Limited attention and the role of the venture capitalist. Journal of Business Venturing, 12: 459-482.

Graham, S. J. H., Merges, R. P., Samuelson, P., \& Sichelman, T. M. 2009. High technology entrepreneurs and the patent system: Results of the 2008 Berkeley patent survey. Berkeley Technology Law Journal, 24: 255-327.

Graebner, M. E. 2009. Caveat Venditor: Trust Asymmetries in Acquisitions of Entrepreneurial Firms. Academy of Management Journal, 52: 435-472.

Gruenfeld, D. H., Inesi, M. E., Magee, J. C., \& Galinsky, A. D. 2008. Power and the objectification of social targets. Journal of Personality and Social Psychology, 95: 111-127.

Gulati, R., \& Higgins, M. C. 2003. Which ties matter when? The contingent effects of interorganizational partnerships on IPO success. Strategic Management Journal, 24: 127-144.

Gulati, R., Lavie, D., \& Madhavan, R. 2011. How do networks matter? The performance effects of interorganizational networks. Research in Organizational Behavior, 31: 207-224.

Guler, I. 2007. Throwing good money after bad? Political and institutional influences on sequential decision making in the venture capital industry. Administrative Science Quarterly, 52: 248-285.
Hall, B. H. 2002. The financing of research and development. Oxford Review of Economic Policy, 18: 35-51.

Hallen, B. L. 2008. The causes and consequences of the initial network positions of new organizations: From whom do entrepreneurs receive investments? Administrative Science Quarterly, 53: 685-718.

Hallen, B. L., \& Eisenhardt, K. M. 2012. Catalyzing strategies and efficient tie formation: How entrepreneurial firms obtain investment ties. Academy of Management Journal, 55: 35-70.

Hallen, B. L., Katila, R., \& Rosenberger, J. D. 2014. How do social defenses work? A resource-dependence lens on technology ventures, venture capital investors, and corporate relationships. Academy of Management Journal, 57: 1078-1101.

Hernandez, E., Sanders, G., \& Tuschke, A. 2014. Network defense: Pruning, grafting, and closing to prevent leakage of strategic knowledge to rivals. Academy of Management Journal: published online ahead of print. DOI: 10.5465/.mj.2012.0773.

Hines, J. Z., Lurie, P., Yu, E., \& Wolfe, S. 2010. Left to their own devices: Breakdowns in United States medical device premarket review. PLoS Medicine, 7: e1000280.

Hochberg, Y. V., Ljungqvist, A., \& Lu, Y. 2007. Whom you know matters: Venture capital networks and investment performance. The Journal of Finance, 62: 251-301.

Hsu, D. H., \& Ziedonis, R. H. 2013. Resources as dual sources of advantage: Implications for valuing entrepreneurialfirm patents. Strategic Management Journal, 34: 761-781.

Jaffe, A. B., Trajtenberg, M., \& Henderson, R. 1993. Geographic localization of knowledge spillovers as evidenced by patent citations. The Quarterly Journal of Economics, 108: 577-598.

Jick, T. D. 1979. Mixing qualitative and quantitative methods: Triangulation in action. Administrative Science Quarterly, 24: 602-611.

Kaplan, S. N., Sensoy, B. A., \& Strömberg, P. 2002. How well do venture capital databases reflect actual investments? (Working Paper, University of Chicago). Chicago: Graduate School of Business, University of Chicago.

Katila, R., \& Chen, E. 2008. Effects of search timing on product innovation: The value of not being in sync with rivals. Administrative Science Quarterly, 53: 593-625.

Katila, R., Rosenberger, J., \& Eisenhardt, K. 2008. Swimming with sharks: Technology ventures, defense mechanisms, and corporate relationships. Administrative Science Quarterly, 53: 295-332.

Katila, R., \& Shane, S. 2005. When does lack of resources make new firms innovative? Academy of Management Journal, 48: 814-829. 
Kerr, W., Nanda, R., \& Rhodes-Kropf, M. 2014. Entrepreneurship as experimentation. The Journal of Economic Perspectives, 28: 25-48.

Khaire, M. 2010. Young and no money? never mind: the material impact of social resources on new venture growth. Organization Science, 21: 168-185.

Khurana, R. 2002. Market triads: a theoretical and empirical analysis of market intermediation. Journal for the Theory of Social Behaviour, 32: 239-262.

Lacy, S. 2010. Comments. In: Andreessen Horowitz isn't hedging its bets with Picplz and Instagram; it has picked Picplz [Blog post], TechCrunch. Retrieved from http://techcrunch.com/2010/11/11/andreessen-horowitzisnt-hedging-its-bets-with-picplz-and-instagram-it-haspicked-picplz/. Posted on November 11, 2010.

Lawler, E. J., \& Yoon, J. 1996. Commitment in exchange relations: Test of a theory of relational cohesion. American Sociological Review, 61: 89-108.

Lee, P. M., Pollock, T. G., \& Jin, K. 2011. The contingent value of venture capitalist reputation. Strategic Organization, 9: 33-69.

Lerner, J. 1995. Venture capitalists and the oversight of private firms. The Journal of Finance, 50: 301-318.

Macgee, J. C., \& Galinsky, A. D. 2008. Social hierarchy: The self-reinforcing nature of power and status. The Academy of Management Annals, 2: 351-398.

Mack, M. J. 2001. Minimally invasive and robotic surgery. Journal of the American Medical Association, 285: $568-572$.

Mansfield, E. 1985. How rapidly does new industrial technology leak out? The Journal of Industrial Economics, 34: 217-223.

Maurer, I., \& Ebers, M. 2006. Dynamics of social capital and their performance implications: Lessons from biotechnology start-ups. Administrative Science Quarterly, 51: 262-292.

Min, Y., \& Agresti, A. 2005. Random effect models for repeated measures of zero-inflated count data. Statistical Modelling, 5: 1-19.

Mishina, Y., Block, E. S., \& Mannor, M. J. 2012. The path dependence of organizational reputation: How social judgment influences assessments of capability and character. Strategic Management Journal, 33: 459-477.

Ozcan, P., \& Eisenhardt, K. M. 2009. Origin of alliance portfolios: Entrepreneurs, network strategies, and firm performance. Academy of Management Journal, 52: 246-279.

Ozmel, U., \& Guler, I. 2014. Small fish, big fish: The performance effects of the relative standing in partners' affiliate portfolios. Strategic Management Journal: published online ahead of print. DOI: 10.1002/ smj.2332.

Pahnke, E. C., Katila, R., \& Eisenhardt, K. in press. Who takes you to the dance? How funding partners influence innovative activity in young firms. Administrative Science Quarterly.

Perlroth, N. 2012. How Andreessen Horowitz bunted on an Instagram investment [Blog post], Bits, New York Times. Retrieved from http://bits.blogs.nytimes.com/ 2012/04/20/how-andreessen-horowitz-fumbled-aninstagram-investment/. Posted on April, 20, 2012.

Pfeffer, J., \& Salancik, G. 1978. The external control of organizations: $A$ resource dependence perspective. New York: Harper \& Row Publishers.

Phelps, C., Heidl, R., \& Wadhwa, A. 2012. Knowledge, networks, and knowledge networks: A review and research agenda. Journal of Management, 38: 1115-1166.

Phelps, C. C. 2010. A longitudinal study of the influence of alliance network structure and composition on firm exploratory innovation. Academy of Management Journal, 53: 890-913.

Phillips, D. J., \& Zuckerman, E. W. 2001. Middle-status conformity: Theoretical restatement and empirical demonstration in two markets. American Journal of Sociology, 107: 379-429.

Piezunka, H., \& Dahlander, L. 2015. forthcoming. Distant search, narrow attention: How crowding alters organizations' filtering of suggestions from crowdsourcing. Academy of Management Journal: published online ahead of print. DOI: 10.5465/amj.2012.0458.

Pisano, G. P., Bohmer, R. M., \& Edmondson, A. C. 2001. Organizational differences in rates of learning: Evidence from the adoption of minimally invasive cardiac surgery. Management Science, 47: 752-768.

Podolny, J. M. 1993. A status-based model of market competition. American Journal of Sociology, 98: 829-872.

Podolny, J. M. 2001. Networks as the pipes and prisms of the market. American Journal of Sociology, 107: 33-60.

Podolny, J. M. 2005. Status signals: A sociological study of market competition. Princeton, NJ: Princeton University Press.

Pollock, T. G. 2004. The benefits and costs of underwriters' social capital in the U.S. initial public offerings market. Strategic Organization, 2: 357-388.

Pollock, T. G., \& Gulati, R. 2007. Standing out from the crowd. The visibility-enhancing effects of IPO-related signals on alliance formation by entrepreneurial firms. Strategic Organization, 5: 339-372.

Pollock, T. G., Porac, J. F., \& Wade, J. B. 2004. Constructing deal networks: Brokers as network "architects" in the 
U.S. IPO market and other examples. Academy of Management Review, 29: 50-72.

Powell, W. W., Koput, K. W., \& Smith-Doerr, L. 1996. Interorganizational collaboration and the locus of innovation: Networks of learning in biotechnology. Administrative Science Quarterly, 41: 116-145.

Rao, L. 2009. While 23andme raises $\$ 11$ million, Mohr Davidow sells stake to invest in rival [Blog post], TechCrunch. Retrieved from http://techcrunch.com/ 2009/05/04/while-23andme-raises-11-million-mohrdavidow-sells-stake-to-invest-in-rival/. Posted on May 4, 2009.

Raub, W., \& Weesie, J. 1990. Reputation and efficiency in social interactions: An example of network effects. American Journal of Sociology, 96: 626-654.

Reagans, R. 2011. Close encounters: Analyzing how social similarity and propinquity contribute to strong network connections. Organization Science, 22: 835-849.

Rindova, V., Pollock, T. G., \& Hawyard, M. L. A. 2006. Celebrity firms: The social construction of market popularity. Academy of Management Review, 1: 50-71.

Roach, M., \& Cohen, W. M. 2013. Lens or prism? Patent citations as a measure of knowledge flows from public research. Management Science, 59: 504-525.

Rogan, M. 2013. Too close for comfort? The effect of embeddedness and competitive overlap on client relationship retention following an acquisition. Organization Science, 25: 185-203.

Rogan, M., \& Sorenson, O. 2014. Picking a (poor) partner: A relational perspective on acquisitions. Administrative Science Quarterly, 59: 301-329.

Sabet, B. 2011. Some thoughts about competitive portfolio companies [Blog post], Bijan Sabet: A personal journal. Retrieved from http://bijansabet.com/post/4106720094/ some-thoughts-about-competitive-portfolio. Accessed on July 15, 2015.

Sahlman, W. A. 1990. The structure and governance of venture-capital organizations. Journal of Financial Economics, 27: 473-521.

Santos, F. M., \& Eisenhardt, K. M. 2009. Constructing markets and shaping boundaries: Entrepreneurial power in nascent fields. Academy of Management Journal, 52: 643-671.

Sapienza, H. J. 1992. When do venture capitalists add value? Journal of Business Venturing, 7: 9-27.

Schilling, M. A., \& Fang, C. 2013. When hubs forget, lie, and play favorites: Interpersonal network structure, information distortion, and organizational learning. Strategic Management Journal, 35: 974-994.

Schoonhoven, C. B., Eisenhardt, K. M., \& Lyman, K. 1990. Speeding products to market: Waiting time to first product introduction in new firms. Administrative Science Quarterly, 35: 177-207.

Semadeni, M. 2001. Toward a theory of knowledge arbitrage: exploring the role of management consultants as knowledge arbitrageurs and arbiters. In A. F. Buono (Ed.), Research in management consulting (Vol. 1): 43-67. Greenwich, CT: Information Age.

Shane, S., \& Cable, D. 2002. Network ties, reputation, and the financing of new ventures. Management Science, 48: 364-381.

Shipilov, A. V. 2006. Network strategies and performance of Canadian investment banks. Academy of Management Journal, 49: 590-604.

Short, J. L., \& Toffel, M. W. 2010. Making self-regulation more than merely symbolic: The critical role of the legal environment. Administrative Science Quarterly, 55: 361-396.

Smith, S. W., \& Shah, S. K. 2013. Do innovative users generate more useful insights? An analysis of corporate venture capital investments in the medical device industry. Strategic Entrepreneurship Journal, 7: 151-167.

Sorenson, O., \& Stuart, T. E. 2001. Syndication networks and the spatial distribution of venture capital investments. American Journal of Sociology, 106: 1546-1588.

Stam, W., \& Elfring, T. 2008. Entrepreneurial orientation and new venture performance: The moderating role of intra-and extra-industry social capital. Academy of Management Journal, 51: 97-111.

Stinchcombe, A. L. 1965. Social structure and organizations. In J. G. March (Ed.), Handbook of organizations: 142-193. Chicago: Rand McNally.

Stuart, T. 2000. Interorganizational alliances and the performance of firms. Strategic Management Journal, 21: 791-811.

Stuart, T., Hoang, H., \& Hybels, R. C. 1999. Interorganizational endorsements and the performance of entrepreneurial ventures. Administrative Science Quarterly, 44: 315-349.

Szulanski, G. 1996. Exploring internal stickiness: Impediments to the transfer of best practice within the firm. Strategic Management Journal, 17 (Winter Special Issue): 27-43.

Teece, D. J. 2007. Explicating dynamic capabilities: the nature and microfoundations of (sustainable) enterprise performance. Strategic Management Journal, 28: 1319-1350.

Thomke, S., \& Nimgade, A. 2000. IDEO product development (Case Study, Harvard Business School, 600143). Boston, MA: Harvard Business School.

Turner, S. F., Mitchell, W., \& Bettis, R. A. 2010. Responding to rivals and complements: How market concentration 
shapes generational product innovation strategy. Organization Science, 21: 854-872.

Ueda, M. 2004. Banks versus venture capital: Project evaluation, screening, and expropriation. The Journal of Finance, 59: 601-621.

Uzzi, B. 1997. Social structure and competition in interfirm networks: the paradox of embeddedness. In M. Granovetter \& R. Swedberg (Eds.), The sociology of economic life: 207-238. Boulder, CO: Westview Press.

Vissa, B. 2011. A matching theory of entrepreneurs' tie formation intentions and initiation of economic exchange. Academy of Management Journal, 54: 137-158.

Vissa, B. 2012. Agency in action: Entrepreneurs' networking style and initiation of economic exchange. Organization Science, 23: 492-510.

Vissa, B., \& Chacar, A. S. 2009. Leveraging ties: The contingent value of entrepreneurial teams' external advice networks on Indian software venture performance. Strategic Management Journal, 30: 1179-1191.

von Hippel, E. 1987. Cooperation between rivals: Informal know-how trading. Research Policy, 16: 291-302.

Wang, D. 2015. Activating Cross-border Brokerage Interorganizational Knowledge Transfer through Skilled Return Migration. Administrative Science Quarterly, 60: 133-176.

Washington, M., \& Zajac, E. J. 2005. Status evolution and competition: Theory and evidence. Academy of Management Journal, 48: 282-296.

Weigelt, K., \& Camerer, C. 1988. Reputation and corporate strategy: A review of recent theory and applications. Strategic Management Journal, 9: 443-454.

Whittington, K. B., Owen-Smith, J., \& Powell, W. W. 2009. Networks, propinquity, and innovation in knowledgeintensive industries. Administrative Science Quarterly, 54: 90-122.

Wilson, F. 2007. Why we don't invest in competitive businesses [Blog entry], Union Square Ventures. Retrieved from https://www.usv.com/blog/whywe-dont-invest-in-competitive-businesses. Posted on January 15, 2007.
Wooldridge, J. M. 2002. Econometric analysis of cross section and panel data. Cambridge, MA: MIT Press.

Wu, B. 2013. Opportunity costs, industry dynamics, and corporate diversification: Evidence from the cardiovascular medical device industry, 1976-2004. Strategic Management Journal, 34: 1265-1287.

Zhang, Y., \& Li, H. 2010. Innovation search of new ventures in a technology cluster: The role of ties with service intermediaries. Strategic Management Journal, 31: 88-109.

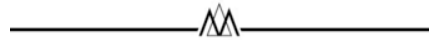

Emily Cox Pahnke (eacox@uw.edu) is an assistant professor of management at the University of Washington. Her research focuses on how the strategies entrepreneurs use to assemble resources impact their innovation and likelihood of being acquired or going public. She received her $\mathrm{PhD}$ in management science and engineering from the Stanford Technology Ventures Program.

Rory McDonald (rmcdonald@hbs.edu) is an assistant professor at Harvard Business School. He studies how firms innovate effectively in new, technology-enabled markets. He received his $\mathrm{PhD}$ in management science and engineering from the Stanford Technology Ventures Program.

Dan Wang (djw2104@columbia.edu) is an assistant professor of management at Columbia Business School. His research focuses on social and organizational networks, knowledge transfer, and globalization. He received his $\mathrm{PhD}$ in sociology from Stanford University.

Benjamin L. Hallen (bhallen@uw.edu) is an assistant professor of management at the University of Washington. His research involves the study of how new actors strategically embed themselves in market networks, with a particular focus on how entrepreneurs obtain investments and resources for young ventures. He received his $\mathrm{PhD}$ in management science and engineering from the Stanford Technology Ventures Program.

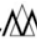

